\title{
Phytoclimatic Stages and Vegetation in Baden - Württemberg and Emilia - Romagna
}

\begin{abstract}
The assessment of ecosystems and landscapes requires reliable and simple tools. Climate determines broad type and distribution of ecosystems. Therefore, it is a major factor to consider in environmental analysis and ecological regionalization. A standardized bioclimatic classification would be useful to characterize and compare different ecosystems. In this paper, Defaut's Phytoclimatic System (DSPS) was tested at regional scale in two European areas: Baden-Württemberg (Germany) and Emilia-Romagna (Italy). DSPS phytoclimatic units and vegetation belts and climatic parameters are illustrated and discussed. In addition, as an example application, a map of phytoclimatic units of Emilia-Romagna is designed. Some challenges in matching vegetation to DSPS were found: 1 ) in areas where transition from one stage to another are not sharply delineated and different vegetation types are intermixed; 2 ) in alluvial lowlands; 3 ) in heavily anthropized areas. In conclusion, the results of this study suggest that DSPS can be a useful tool in ecological regionalization and in landscape analysis.
\end{abstract}

Dario Botti*

Independent professional

*Corresponding author: Dario Botti, via D. Galimberti, 10; 43123 Parma (Italy); Email: dario.botti@libero.it

\section{Keywords:}

Germany, Italy, climate classification, ecological regionalization, landscape ecology, GIS mapping. 


\section{Introduction}

\subsection{Motivation}

Climate, vegetation and their relationships can be analysed in many different ways. Usefulness of a particular method depends on the purposes and aims of the analysis. This paper is focused on use of phytoclimates in ecological regionalization.

Assessment of ecosystems and landscapes needs reliable and simple tools. European and international cooperation in general also needs standardized methods to analyse ecosystems. Climate determines broad types and distribution of vegetation and ecosystems (Walter 1985; Box \& Fujiwara 2005). Therefore, it is a major factor to consider in environmental analysis and ecological regionalization (see, e.g. Forman \& Godron 1986; Bailey 1987; Klijn \& de Haes 1994).

Vegetation is the most evident feature of the majority of terrestrial ecosystems and expresses the environmental factors for a given ecosystem (Emberger 1939). Therefore, a standardized bioclimatic classification correlated with vegetation (i.e. a phytoclimatic one) would be useful to characterize and compare different ecosystems.

Because of the importance of vegetation as indicator of ecological conditions, phytoclimatic classifications are also helpful in the analysis of other aspects of ecosystems and anthropogenic landscapes where natural vegetation is modified, degraded or even removed. In addition, they are important tools in the assessment and prediction of changes in vegetation induced by climate change.

Many successful systems to correlate vegetation and climate (and environmental conditions in general) do exist (Box 1981). According to Bailey (2009) all systems are useful but each is better suited to a particular region of the earth. In this paper, the "System of Phytoclimatic Stages" (hereinafter "DSPS") developed by Defaut (1996) was tested at a regional scale in Baden-Württemberg (Germany) and Emilia-Romagna (Italy).

\subsection{Defaut's System of Phytoclimatic Stages (DSPS)}

Emberger's works (1955, 1964, in Defaut 1996) inspired Defaut's "system of phytoclimatic stages" (Defaut 1991, 1992, 1996, 2015). Different from the former system, limited in its use to the Mediterranean zone, or to a zone that has only one climatic regime (Morat 1969), this latter system was devised for the entire Palearctic Domain.

DSPS distinguishesthreelarge groups of phytoclimatic stages. In the driest group (xeric bioclimates) the different stages are mainly under the influence of aridity-humidity parameter, and secondarily under the influence of average annual temperature or thermal expression of continentality. In the wettest (axeric bioclimates) and transition groups (subxeric bioclimates), vegetation stages are mainly under the influence of the average annual temperature (or summer temperature for the coldest stages) and secondarily under the control of thermal continentality.

The phytoclimatic stage of a site is determined by its position on the climagram " $\mathrm{T}, \mathrm{tc}, \mathrm{Qn2}$ " (Figure 1), where " $T$ " is average annual temperature, "tc" the mean temperature of the warmest month (" $c$ " from the French word, "chaud", meaning "warm"), "Qn2" the aridity/humidity index (Defaut 1996). Defaut traced the borders of phytoclimatic stages directly from patterns shown by zonal/etageal potential vegetation (i.e. whenever possible, the highest rank phytosociological syntaxa) of 542 weather stations plotted on his climagram (Figure 1). In the climagram in Figure 1 are shown (simplified) the major characteristic syntaxa (or, in some cases, vegetation formations) of each phytoclimatic stage. For a detailed account of each phytoclimatic stage, associated vegetation and morphogenetic/ sedimentary phenomena, the reader is referred to Defaut (1996).

\subsection{Goals of the study}

DSPS, being focused on Palearctic and based largely on phytosociological syntaxa, (instead of on generic plant formations) is better suited for ecological regionalization rather than other global but more 


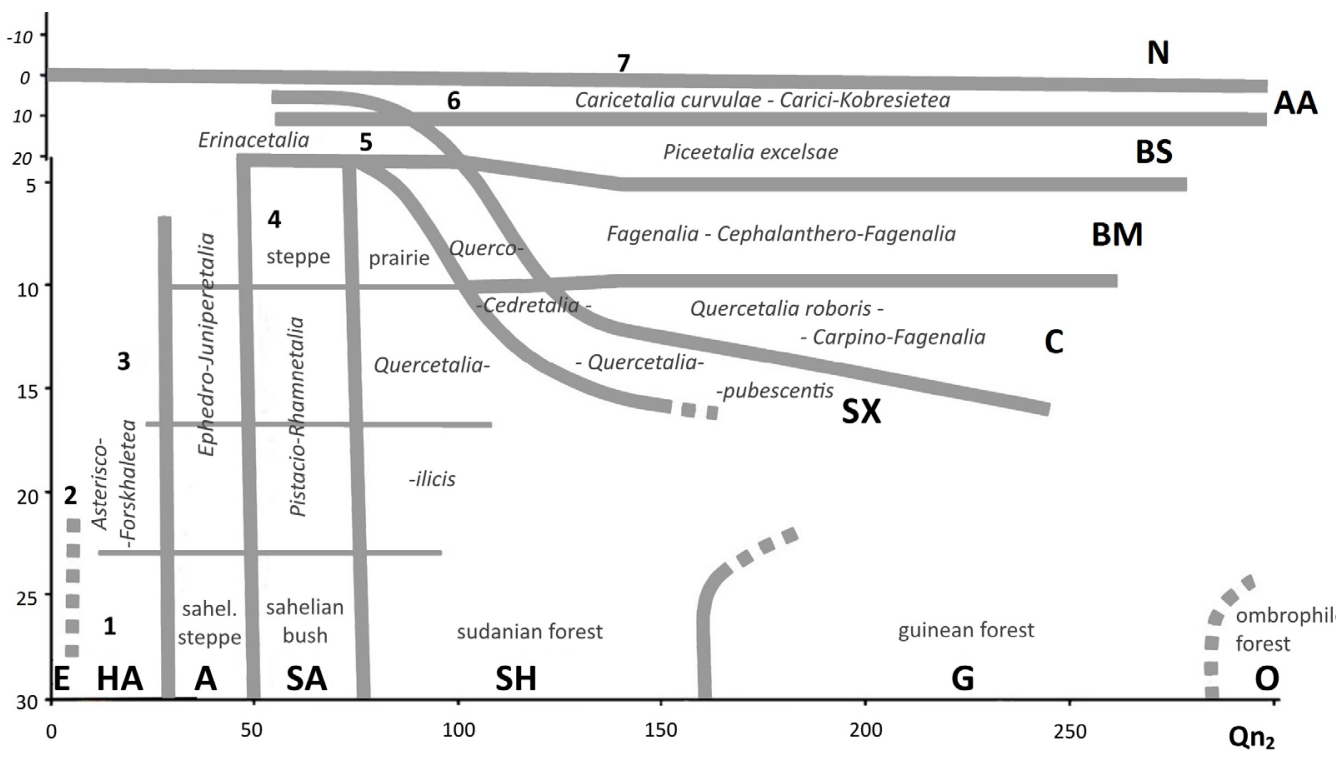

Figure 1: Climagram "T, tc, Qn2". Legend: tc, mean temperature of warmest month; T, annual mean temperature; Qn2, aridity/humidity index; E, Eremic; HA, Hyperarid; A, Arid; SA, Subarid; SH, Subhumid; SX, Subxeric; C, Colline; BM, Boreo-Montane; BS, Boreo-Subalpine; AA, Arctic-Alpine; N, Nival; G, Guinean; O, Ombrophilous; 1, Very hot; 2, Hot; 3, Temperate; 4, Cool; 5, Cold; 6, Very cold; 7, Nival. After Defaut (2015), slightly modified.

generic (bio)climatic classifications. The main goal of this study was testing DSPS at relatively detailed scale for purposes of ecosystem characterization, landscape analysis and ecological regionalization.

\section{Materials and methods}

\subsection{Choice of study areas}

In this paper, phytoclimatic stages of two European areas: Baden-Württemberg (hereinafter referred to as "B-W") in Germany and Emilia-Romagna (hereinafter referred to as "E- $R$ ") in Italy (Figure 2) are analysed and compared. Administrative units, (instead of natural ones) are used due to the availability of studies and homogeneous collected data.

These two geographical areas were chosen because they:

- support many vegetation types,

- have a varied geomorphology, with low alluvial plains and topographical relief with altitudinal zonation (Figure 3),

- are in contrasting positions with respect to Alps,
- are under contrasting affects from the Atlantic ocean and Mediterranean sea,

- are comparable in extent,

- much data are available regarding vegetation and climate.

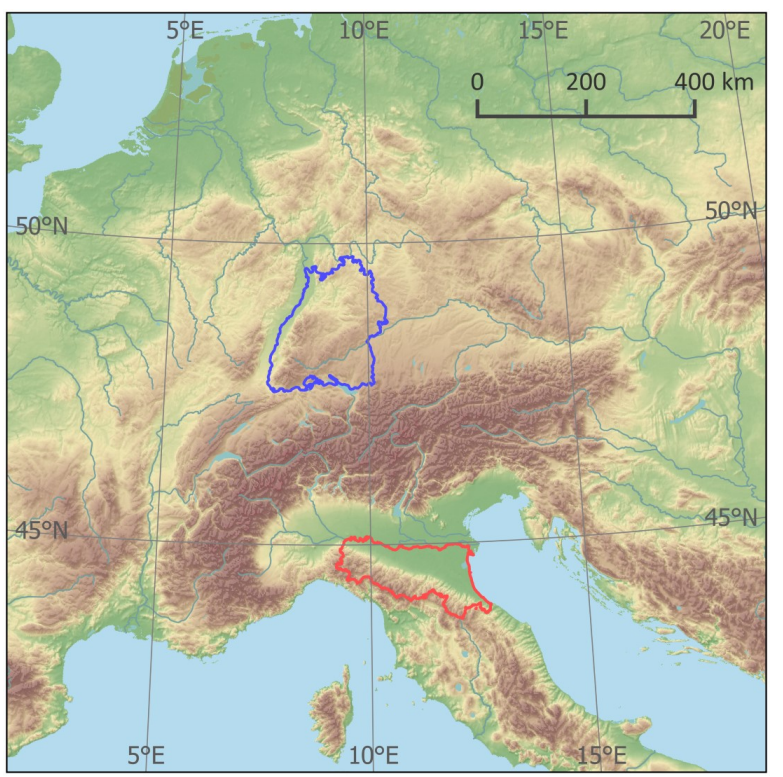

Figure 2: Location of study areas: Baden-Württemberg (in blue) and Emilia-Romagna (in red). Sources: elevation map of Europe, European Environment Agency (EEA); lakes, rivers and shaded relief, Natural Earth; borders of study areas, (CGeoBasis-DE/ BKG2015 and Istituto Nazionale di Statistica (ISTAT). Geodatabase created by the author. 

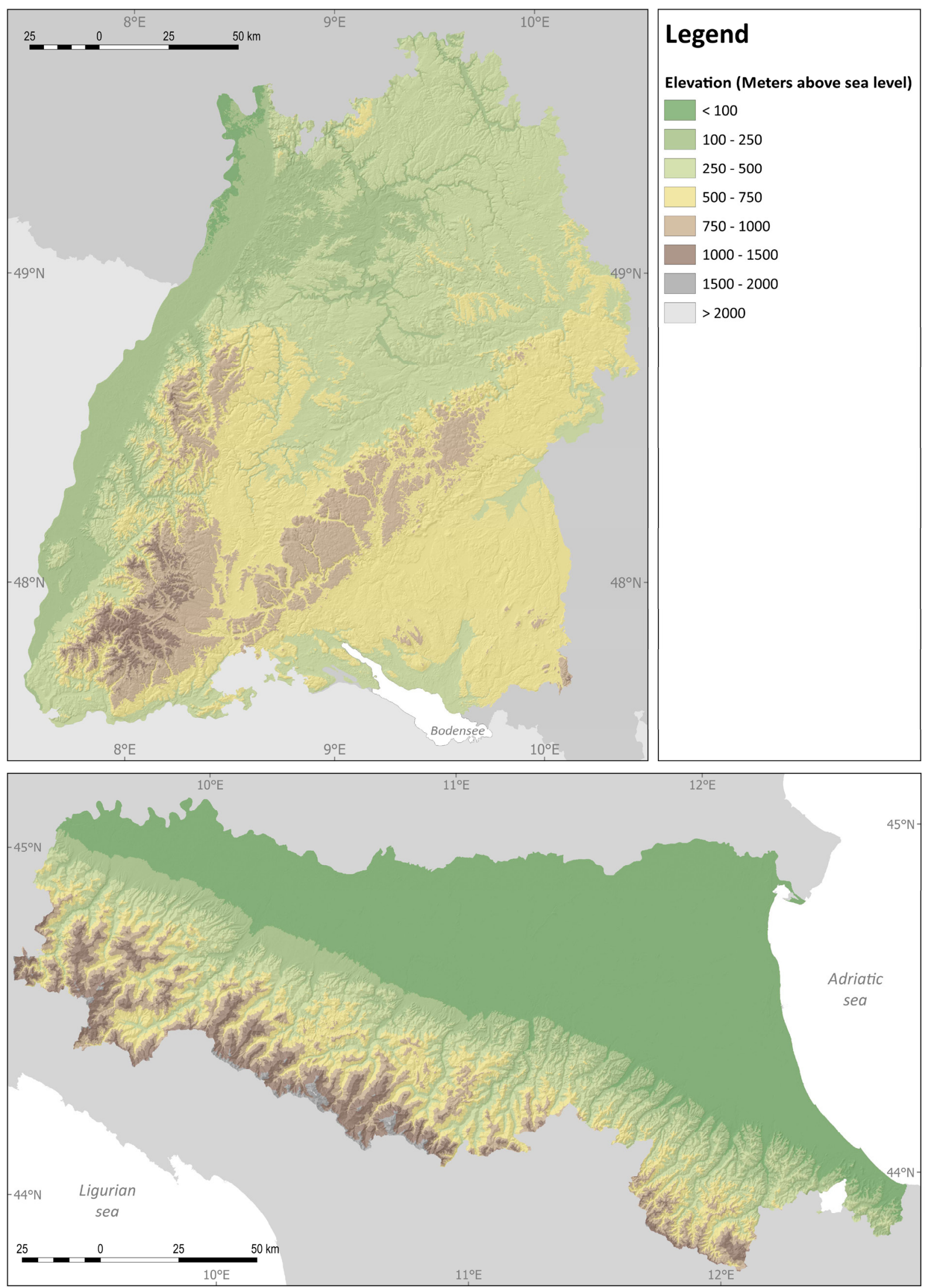

Figure 3:Hillshaded elevation maps of Baden-Württemberg (above) and Emilia-Romagna (below). Sources: EU-DEM by Copernicus - European Union; (CGeoBasis-DE/BKG2015; Istituto Nazionale di Statistica (ISTAT); Regione EmiliaRomagna. Geodatabase and maps created by the author. 


\subsection{General information on geography, climate and vegetation of the study areas}

Baden-Württemberg is located in the Hercynian Central Europe (Bohn et al. 2000/2003) and covers $35,751 \mathrm{~km}^{2}$ (Baden-Württemberg 2016). It borders the river Rhine (West), lake Constance (South) and includes the Schwarzwald mountain range (Figure 3, above).

According to Troll \& Paffen (1964), the area falls in the Cool-temperate zone and has a Suboceanic climate (III3). Troll \& Paffen's map is designed on a very small scale, so that no mountain zone altitude climate is shown in the area. According to Walter et al. (1975, in Bohn et al. 2000/2003) BadenWürttemberg has a typical Temperate climate (VI), except for the Schwarzwald, which has a mountain climate $(X)$.

Excluding azonal vegetation, in Baden-Württemberg there are two main formations (Bohn et al. 2000/2003): "Mesophytic and hygromesophytic coniferous and mixed broad-leaved-coniferous forests", and "Mesophytic deciduous broadleaved forests and mixed coniferous-broad-leaved forests". The first formation includes the "Montane to altimontane, partly submontane fir and spruce forests in the nemoral zone" of Schwarzwald (Figure 4a). The second formation includes the "Montane to altimontane [beech and mixed beech forests], partly with fir and spruce" (Figure 4b, c), the "Lowland to submontane [beech and mixed beech forests]" (Figure 4d) and the "Mixed oak-hornbeam forests" of the Rhine valley.
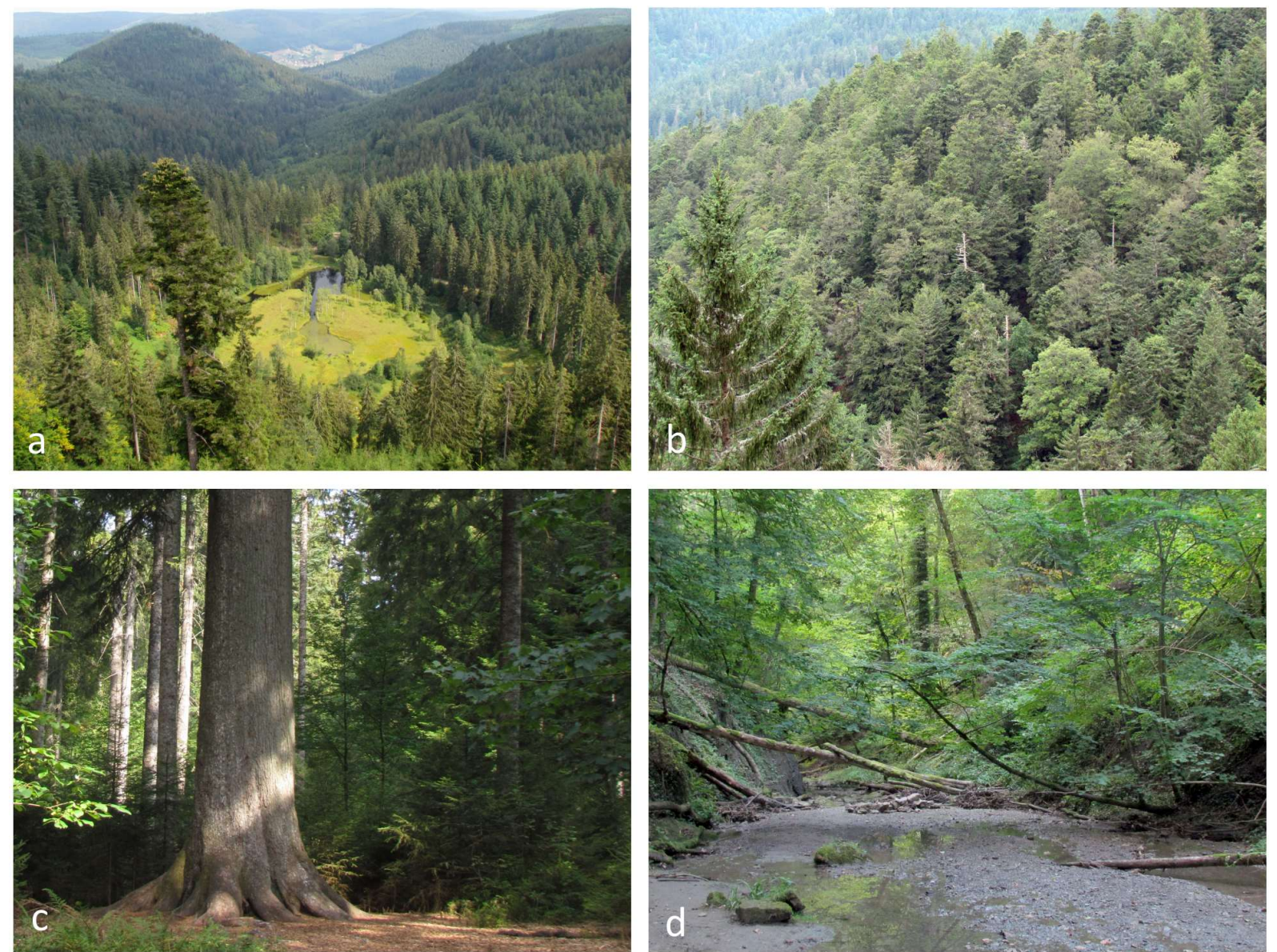

Figure 4: Some vegetational aspects of Baden-Württemberg: a, altimontane (around the lake) and montane (background) spruce-fir-beech forest (Ellbachsee - North Schwarzwald); b, montane fir-beech forest (Schwarzahalden, Hochschwarzwald); c, montane fir-beech forest (Freudenstadt, North Schwarzwald); d, submontane mixed forest (Zillhausen, Schwäbische Alb). Photographs by the author. 
Emilia-Romagna covers the southeast part of the North Italian lowland and northeast slopes of Apennine peninsula (Bohn et al. 2000/2003). It lies between the Po river (North), Adriatic Sea (East) and the Apennine ridge (South) (Figure 3 below). The area investigated in this study includes former regional borders before the 2009 expansion and covers 22,123 km2 (Touring Club Italiano "TCl" 2005). Former borders were chosen instead of current ones in order to have homogeneous data.

According to Troll \& Paffen (1964), the area falls in the Cool-temperate zone and has a Suboceanic climate (III3). In the paper accompanying the map, Troll specifies that Northern Italy (including EmiliaRomagna), among other areas, is Submediterranean, because of its warm but not dry summer. Apennine's highlands are mapped as climatic mountain altitudes. Also according to Walter et al. (1975, in Bohn et al. 2000/2003) the Apennines have a mountain climate
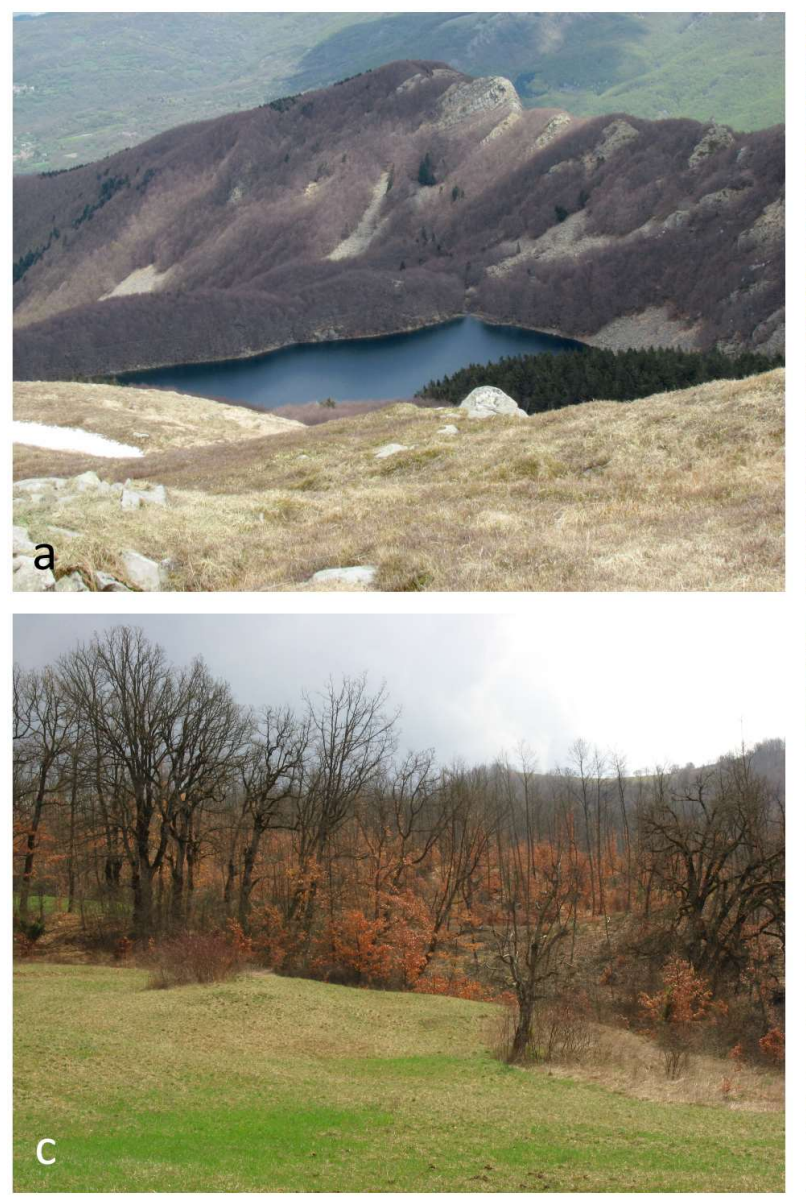

$(X)$, whereas the lowlands fall in a transitional (Submediterranean) climatic zone (IV-VI), between the typical Mediterranean climate (IV) and typical Temperate climate (VI).

Excluding azonal vegetation, in Emilia-Romagna there are the following main formations (Bohn et al. 2000/2003): "Arctic tundras and alpine vegetation", "Subarctic, boreal and nemoral-montane open woodlands as well as subalpine and oroMediterranean vegetation"(Figure 5a), "Mesophytic deciduous broad-leaved and mixed coniferousbroad-leaved forests"(Figure 5a, b), "Thermophilous mixed deciduous broad-leaved forests"(Figure 5c) and "Mediterranean sclerophyllous forests and scrub" (Figure 5d).

The transitional nature of E-R challenges ecological classifications and regionalization and makes it a good testing area.
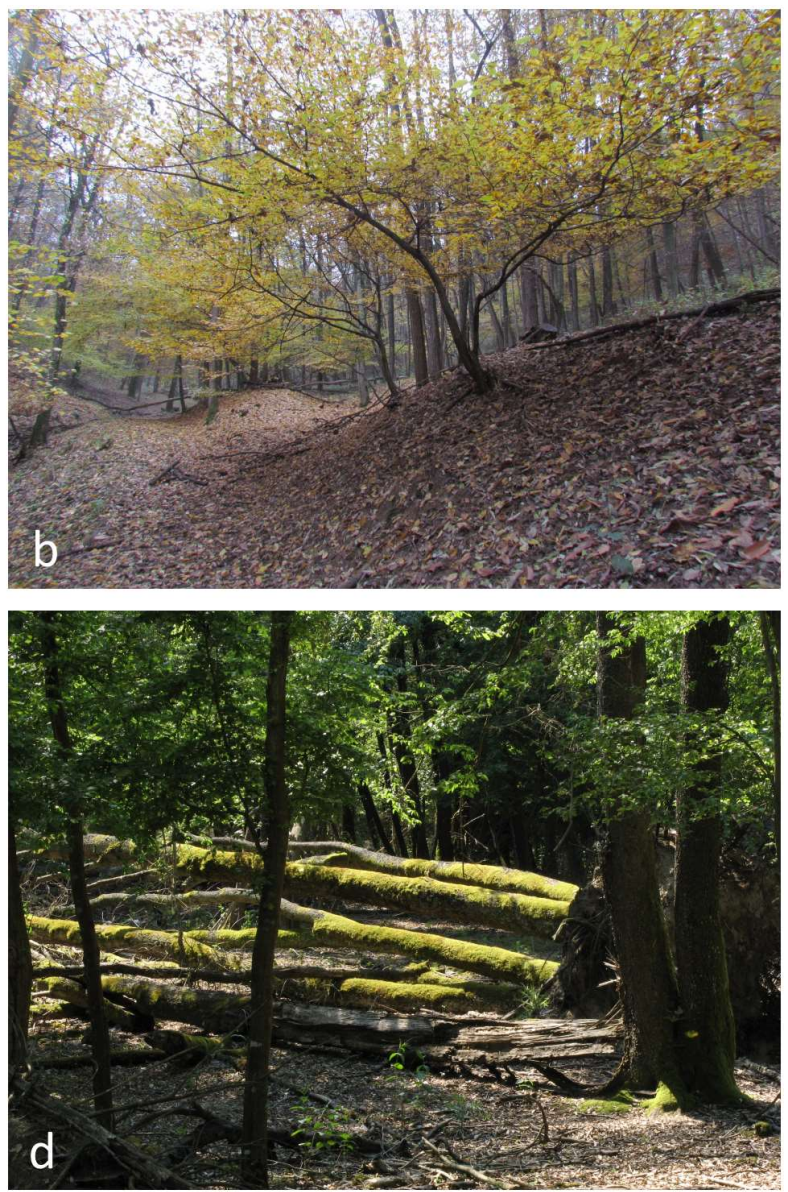

Figure 5: Some vegetational aspects of Emilia-Romagna: a, submontane mixed forest (pale green woods in background), montane beech forest (brown woods around the lake), suprasylvatic grassland (foreground) seen from Apennine's ridge in early spring (Monte Marmagna, Appennino Parmense); b, hornbeam-pedunculate oak forest (Boschi di Carrega, Apennine margin); c, bitter oak - hop hornbeam wood in early spring (Ghirardi, Appennino Parmense); d, sclerophyillous forest (Mesola - Po Delta). Photograps by the author. 


\subsection{Data}

Phytoclimatic classification of the study areas was based on monthly climatic normals over three decades 1961-90. GIS mapping was based on data from 134 meteorological stations in and around Baden-Württemberg (Mühr 2016), and on data from 214 meteorological stations in and around EmiliaRomagna (Agenzia regionale per la prevenzione, I'ambiente e l'energia dell'Emilia-Romagna "Arpae" 2016; Mühr 2016; Federal Office of Meteorology and Climatology "Meteoswiss" 2016; Agenzia regionale per la protezione dell'ambiente ligure "Arpal" 2016; Wikipedia 2016; Perosino \& Zaccara 2006).

To develop the phytoclimatic maps, the European Digital Elevation Model (EU-DEM) by CopernicusEuropean Union was used. EU-DEM has a spatial resolution of $25 \mathrm{~m}$.

To compare phytoclimatic stages and vegetation (or vegetation belts), data from 86 meteorological stations of Baden-Württemberg (Mühr 2016) and from 48 meteorological stations of Emilia-Romagna (Arpae 2016) were used. In addition, a series of data from Emilia-Romagna (Arpae 2016) related to 63 weather stations (years 1991-2005) was also analysed.

Vegetation belts and complexes used for testing the phytoclimatic classification were based on: potential natural vegetation of Baden-Württemberg at scale 1:200,000 (paper maps and accompanying notes; hereinafter also referred to as "PNV2013") (Reidl et al. 2013); 1974's map of potential natural vegetation of Baden-Württemberg (document in PDF format; hereinafter also referred to as "PNV1974") (Müller et al. 1974, in Landesanstalt für Umwelt BadenWürttemberg - LUBW 1992); Baden-Württemberg's forestry stand map (Forstliche Versuchs- und Forschungsanstalt Baden-Württemberg 1997, in Reidl et al. 2013) (hereinafter also referred to as Regional/Zonal forest map, "RZF"); regional phytoclimatic map of Emilia-Romagna at scale 1:500,000 (paper map and accompanying notes; hereinafter also referred to as "RPM") (Ubaldi et al. 1996); further data from Ferrari (1997), Puppi Branzi (1997) and Tomaselli (1997)“.

\subsection{Determination of phytoclimatic stages}

In order to classify phytoclimatic stages of known sites, the Defaut (1996) method was followed. Meteorological stations were plotted as points on the climagram " $\mathrm{T}, \mathrm{tc}, \mathrm{Qn2}$ " according to values of their climatic parameters. Position of a point in the climagram gives the phytoclimatic stage. Climatic parameters used by Defaut's system are the following:

- average annual temperature $\mathrm{T}$ (in $\left.{ }^{\circ} \mathrm{C}\right)$,

- average monthly temperature of the warmest month tc (in ${ }^{\circ} \mathrm{C}$ ) for the stations with $\mathrm{T}<4.5^{\circ} \mathrm{C}$ $\left( \pm 0.5^{\circ} \mathrm{C}\right)$,

- thermal continentality tc-tf (in ${ }^{\circ} \mathrm{C}$ ), where tf is the average monthly temperature of the coldest month ("f" from the French word, "froid", meaning "cold"),

- aridity index Qn2 (Defaut, 1991), calculated as following:

$$
\text { Qn2 }=10 \sqrt{\frac{50\left(P+10 P^{\prime}\right)}{(T+30)(t c-t f)}}
$$

where $P$ is the average annual rainfall and $P^{\prime}$ the cumulative rainfall of the driest consecutive three months ("dry" sensu Gaussen 1957, in Defaut 1996) where dryness is inversely proportional to the ratio between annual rainfall and average temperature.

Tables 1, 2 and 3 show respectively classes of temperature, continentality and aridity/humidity. Note that the classes of aridity/humidity do not have fixed numeric intervals, but are visually determined in the climagram (Figure 1). In the climagram, the $x$ axis shows the values of Qn2, the $y$ axis shows the values of $\mathrm{T}$ and $\mathrm{tc}$. When $\mathrm{T}<4.5^{\circ} \mathrm{C}$, it is replaced by tc without breaking the continuity of the boundary between phytoclimatic stages.

For each meteorological station tc-tf and Qn2 were calculated and then assigned the corresponding zonal/etageal potential vegetation from the following maps: Baden-Württemberg's Potential Natural Vegetation map (Reidl et al. 2013), Baden-Württemberg's Regional/Zonal forest 
map (Forstliche Versuchs- und Forschungsanstalt Baden-Württemberg 1997), the 1974 map of Baden-Württemberg's Potential Natural Vegetation (Müller et al. 1974) and Emilia-Romagna's Regional Phytoclimatic map (Ubaldi et al. 1996). In assigning vegetation belt to E-R's stations, to avoid errors due to the small scale of the map, the elevation above sea level also has been taken into account according to experienced judgment. The weather stations were then plotted on Defaut's climagram " $\mathrm{T}, \mathrm{Tc}$, Qn2" (Figure 7a-f).

To compare phytoclimatic stages and RPM, the "phytoclimatic landscapes" of the map were grouped in five belts as follows:

- "l" - Lowland, the entire regional plain, quantitatively separated from the Apennine as explained below (point 2.5), (letter " $\mathrm{P}$ " in Figure 10);
- " $x w "$ - Warm submediterranean: the lower submediterranean belt in sectors 3-5 (numbers 3-5 in Figure 10);

- "xc" - Cool submediterranean: the upper submediterranean belt, in sectors (numbers 3-5 in Figure 10);

- "xi" - Intermediate submediterranean: the submediterranean belts in sectors 1-2 (numbers 1-2 in Figure 10);

- "m" - montane: all Apennine highlands above submediterranean belts, including the suprasylvatic belt.

Table 1: Classes of temperature: " $\mathrm{T}$ " is the mean annual temperature in ${ }^{\circ} \mathrm{C} ;$ " $\mathrm{tc}$ " is the mean temperature of the warmest month in ${ }^{\circ} \mathrm{C}$. Source: Defaut (1996).

\begin{tabular}{|l|l|l|}
\hline Code & Name & Range \\
\hline 1 & Very hot & $23.0^{\circ} \mathrm{C}( \pm 2) \leq \mathrm{T}$ \\
\hline 2 & Hot & $16.5^{\circ} \mathrm{C}( \pm 1)<\mathrm{T}<23.0^{\circ} \mathrm{C}( \pm 2)$ \\
\hline 3 & Temperate & $10.0^{\circ} \mathrm{C}( \pm 1)<\mathrm{T}<16.5^{\circ} \mathrm{C}( \pm 1)$ \\
\hline 4 & Cool & $4.5^{\circ} \mathrm{C}( \pm 0.5)<\mathrm{T}<10.0^{\circ} \mathrm{C}( \pm 1)$ \\
\hline 5 & Cold & $10.5^{\circ} \mathrm{C}<$ tc et $\mathrm{T}<4.5^{\circ} \mathrm{C}( \pm 0.5)$ \\
\hline 6 & Very cold & $2.0^{\circ} \mathrm{C}( \pm 2)<$ tc $<10.5^{\circ} \mathrm{C}$ \\
\hline 7 & Nival & tc $\leq 2.0^{\circ} \mathrm{C}( \pm 2)$ \\
\hline
\end{tabular}

Table 2: Classes of thermal continentality: "tc" is the mean temperature of the warmest month in ${ }^{\circ} \mathrm{C}$; " $t f$ " is the mean temperature of the coldest month in ${ }^{\circ} \mathrm{C}$. Source: Defaut (1996).

\begin{tabular}{|l|l|l|}
\hline Code & Name & Range \\
\hline a & Hyperoceanic & $9^{\circ} \mathrm{C} \geq$ tc-tf \\
\hline b & Oceanic & $16^{\circ} \mathrm{C}>$ tc-tf $>9^{\circ} \mathrm{C}$ \\
\hline c & Suboceanic (= Subcontinental) & $22^{\circ} \mathrm{C}>$ tc-tf $>16^{\circ} \mathrm{C}$ \\
\hline d & Continental & $42^{\circ} \mathrm{C}>$ tc-tf $>22^{\circ} \mathrm{C}$ \\
\hline e & Hypercontinental & tc-tf $\geq 42^{\circ} \mathrm{C}$ \\
\hline
\end{tabular}


Table 3: Classes of aridity/humidity. Source: Defaut (1996).

\begin{tabular}{|l|l|}
\hline Code & Name \\
\hline E & Eremic \\
\hline HA & Hyperarid \\
\hline A & Arid \\
\hline SA & Semiarid \\
\hline SH & Subhumid \\
\hline SX & Subxeric (or Subaxeric) \\
\hline AX & Axeric \\
\hline
\end{tabular}

\subsection{GIS mapping}

For each study area, a map of phytoclimatic stages (Figure 9) was produced. An additional map was developed to show in greater detail the phytoclimatic units of Emilia-Romagna. QGIS (version 2.10.1) and SAGA GIS (version 5.0.0) (Conrad et al. 2015) softwares were used.

The mapping process was based upon the following steps (see also Figure 6):

1. Assignment of a numerical value to each class of temperature, aridity/humidity and thermal continentality;

2. Determination of class of temperature, aridity/humidity and thermal continentality of each meteorological station and corresponding numerical value;

3. Creation of a point vector with the meteorological stations so classified;

4. Creation of three grids (one grid respectively for temperature, for aridity/humidity and for continentality classes) based on point vector referred to above and on the EU-DEM, by using "Universal Kriging" tool in SAGA GIS with a spatial resolution of $100 \mathrm{~m}$;
5. Creation of three contour maps (one for each attribute) from the three grids by using the "Contour Lines from Grid" tool in SAGA GIS. A contour interval of 1.00 was chosen;

6. Creation of the final phytoclimatic map by intersection of the three contour maps.

To develop the second and more detailed phytoclimatic map of E-R (Figure 10), the same sequence was followed, but the interval chosen for contour lines was 0.25 in order to subdivide temperature classes in quarters.

In addition, in the E-R map:

1. The Apennine forest sectors were implemented through intersection of a further polygon vector containing forest sectors. Forest sectors are based on Ubaldi et al. (1996), but for practical purposes here, their boundaries are slightly modified to follow orographical features. Note, different from RPM, but according to RPM's illustrating notes, sectors 1 and 2 here also include the montane belt;

2. Apennine topographic relief was separated from Po plain by using mean slope (Scripter 1970; Iwahashi \& Pike 2007). Following this scope, a slope grid based on EU-DEM was created by using the "Slope" tool in SAGA GIS. 


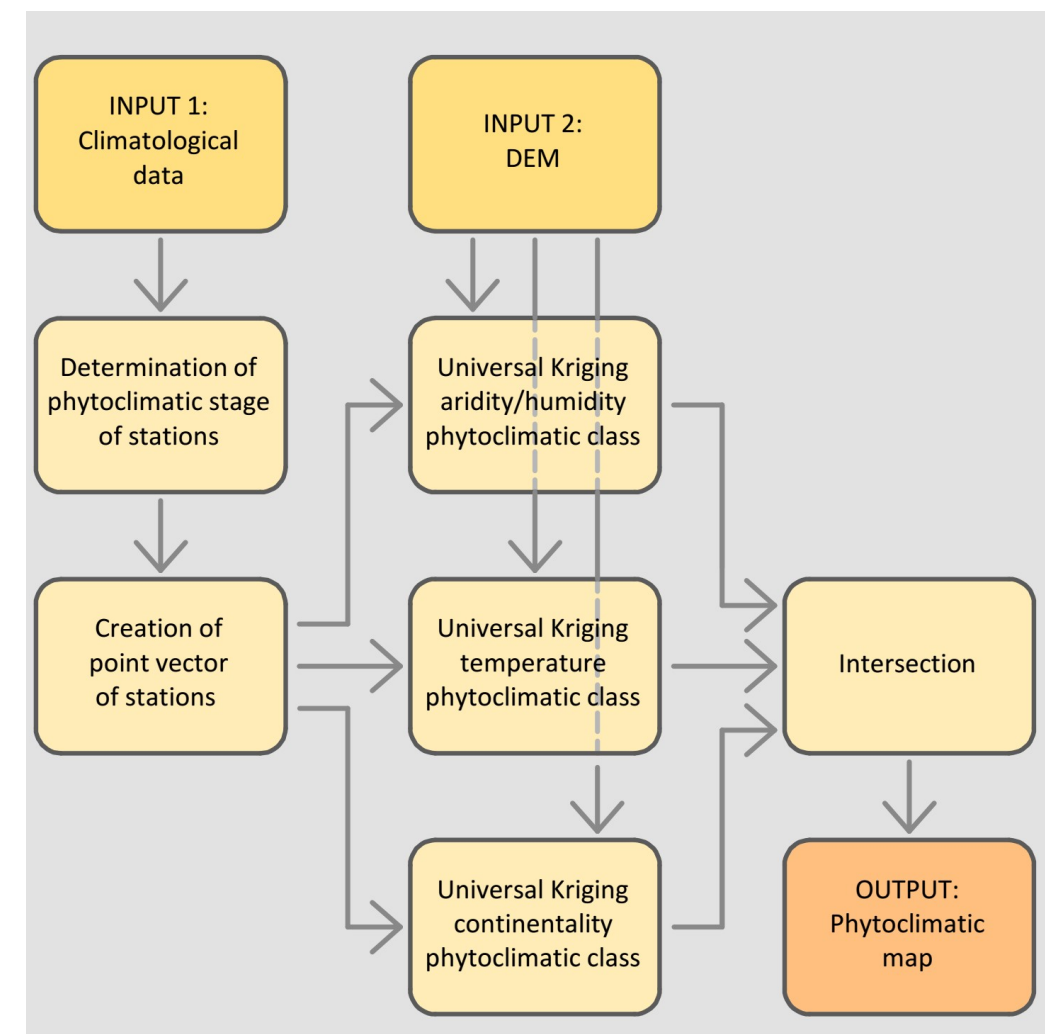

Figure 6: Schematic workflow of GIS mapping. DEM, Digital Elevation Model. Created by the author.

\section{Results}

\subsection{Climagrams}

B-W and E-R weather stations, plotted according to their climatic parameters on the climagram, are shown in Figures 7a-f. Figure 7a shows B-W's and E-R's weather stations plotted together. Figure $7 \mathrm{~b}$ shows E-R's meteorological stations. Points form a cloud going from lower-left to upper-right. Figures 7c-f show B-W's meteorological stations. They are more evenly distributed than those of E-R. The points form a nearly continuous cloud from Colline to BoreoSubalpine stage. However, a gap exists between the two points in the BS stage and the wettest points in BM stage. The colder stations $\left(\mathrm{T} 5.5-5.8^{\circ} \mathrm{C}\right)$ of montane belt are aligned near the limit between $\mathrm{BM}$ and $\mathrm{BS}$ stages while their moisture $\left(\mathrm{Qn}_{\mathrm{n}}\right)$ varies from around 180 to 230. Phytoclimatic stages of Baden-Württemberg were compared to vegetation altitudinal belts as expressed in the PNV2013 map and in the RZF map. Such a comparison was made using occurrence of weather stations in each belt and stage (Figures 7c and 7d). The PNV2013 map of Baden-Württemberg (Reidl et al. 2013), recognizes four elevation belts. These are the Lowland-Colline, the Submontane, the Montane and the Altimontane. The belts are plotted on a floristic (phytosociological) basis. According to map's authors, distinguishing elevation belts in Baden-Württemberg is difficult, particularly in areas where soils are poor and the number of species is low. Clusters of points show that boundaries between lowland-colline, submontane and montane belts go from upper-left to lower-right. Both B-W climagrams, based on RZF and PNV2013 show the same pattern of altitudinal belts (except for the boundary between lowland and colline belt in RZF climagram that is somewhat parallel to boundary $\mathrm{C}-\mathrm{BM})$.

For comparison, weather stations of B-W were also plotted classified according to vegetation classes of PNV1974 (Müller et al. 1974) and according to vegetation complexes of PNV2013 (Reidl et al. 2013), as shown, respectively, in Figure $7 \mathrm{e}$ and Figure $7 \mathrm{f}$. In PNV1974, beech-oak forests (two points) are found in C stage, in the warmest and driest sites. Oak-hornbeam forests are found in warm and dry 
sites, partly in C stage, partly in BM stage. Beech forests are found mostly in the warmest sites of BM stage, and a few sites of $C$ stage. Fir-beech forests are found in BM stage (except one in BS stage) from warm and moderately moist sites to cool and wet sites. Fir forests are located in BM stage (except one in BS stage), in sites with intermediate moisture between beech and fir-beech forests. In PNV2013, complexes of Luzulo-Fagion - Fagion - Carpinion Quercion are widely distributed in sites of $C$ and BM stages. They occur from warmest and driest sites to moderately wet and cool sites. Complexes of LuzuloFagion - Fagion sylvaticae are found mostly in BM stage, relatively few in C stage and one in BS stage. They occur in sites throughout the entire range of temperature and moisture. Complexes of LuzuloFagion - Fagion - Piceion are located in BM stage (except one in BS stage), in sites with intermediate to high moisture. Finally, complexes of Luzulo-Fagion Fagion - Carpinion - Piceion (two points) are located in dry and medium moist sites in BM stage.

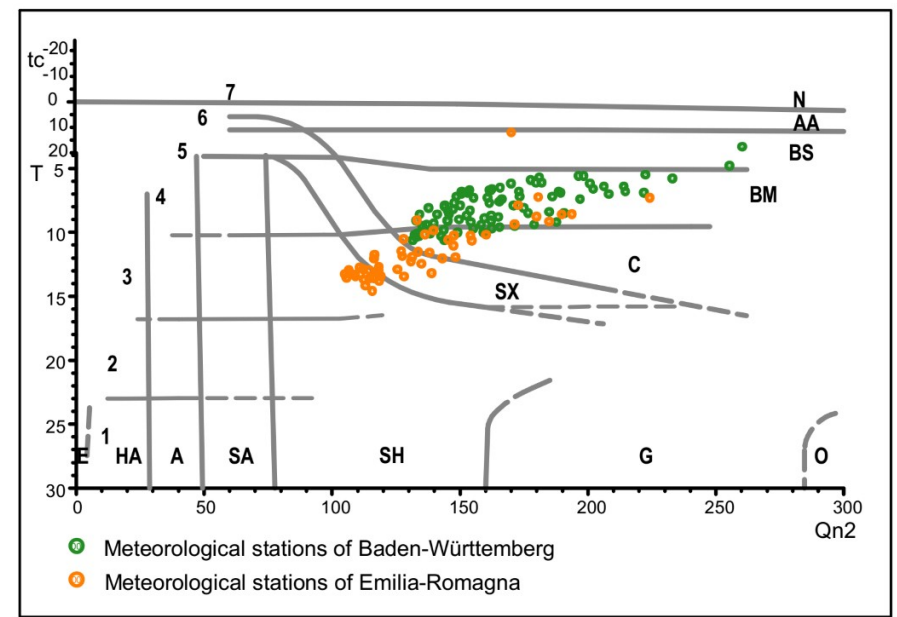

a)

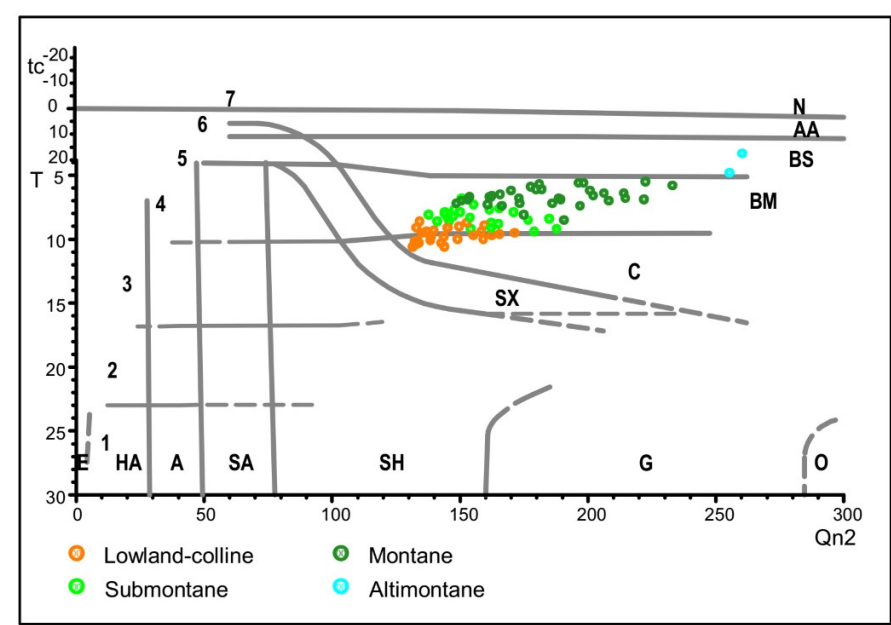

c)

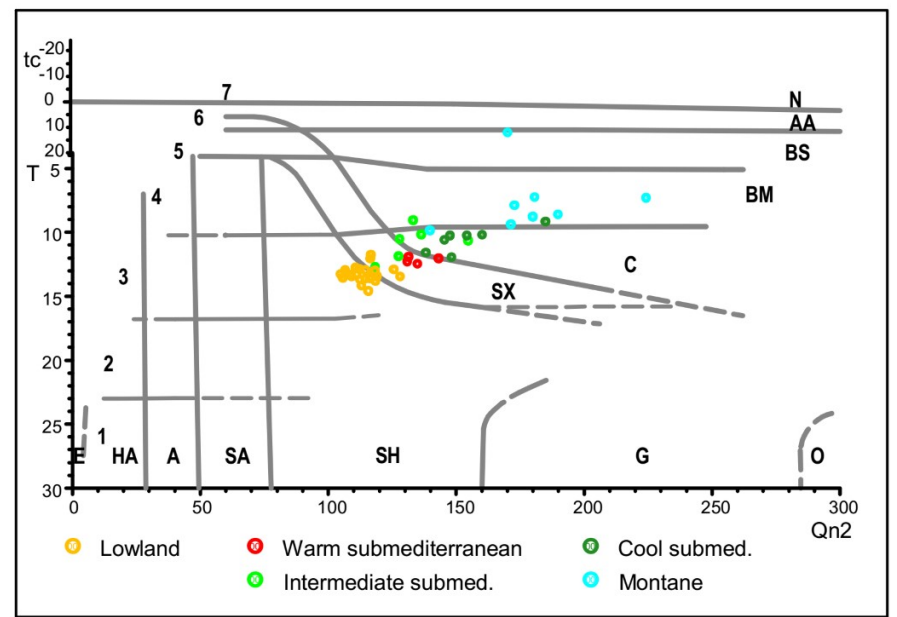

b)

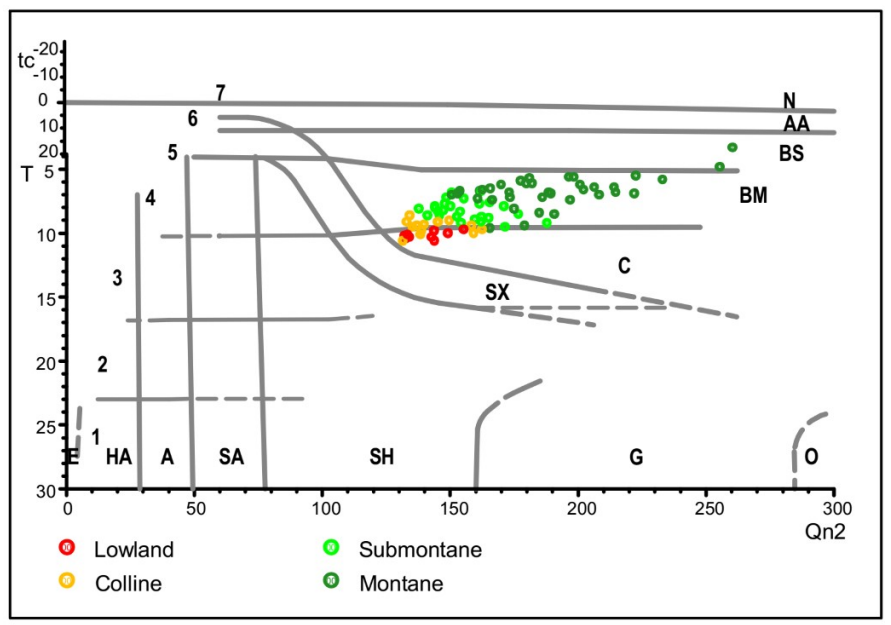

d)

Figure 7: Climagrams. a) Stations of Baden-Württemberg (B-W) and Emilia-Romagna(E-R) plotted together. b) E-R, altitudinal belts according to regional phytoclimatic map. c) B-W, altitudinal belt according to RZF. d) B-W, according to PNV2013. Legend: PNV1974, Potential Natural Vegetation map (Müller et al. 1974); PNV2013, Potential Natural Vegetation map (Reidl et al. 2013); RZF, Regional/Zonal forest map (Forstliche Versuchs- und Forschungsanstalt BadenWürttemberg 1997); C, Carpinion betuli; Q, Quercion roboris; L, Luzulo-Fagion; F, Fagion sylvaticae; P, Piceion abietis; tc, mean temperature of warmest month; T, annual mean temperature; Qn2, aridity/humidity index; E, Eremic; HA, Hyperarid; A, Arid; SA, Subarid; SH, Subhumid; SX, Subxeric; C, Colline; BM, Boreo-Montane; BS, Boreo-Subalpine; AA, Arctic-Alpine; N, Nival; G, Guinean; O, Ombrophilous; 1, Very hot; 2, Hot; 3, Temperate; 4, Cool; 5, Cold; 6, Very cold; 7, Nival. Climagram after Defaut (2015), slightly modified; vegetational and climatic data: see text. 


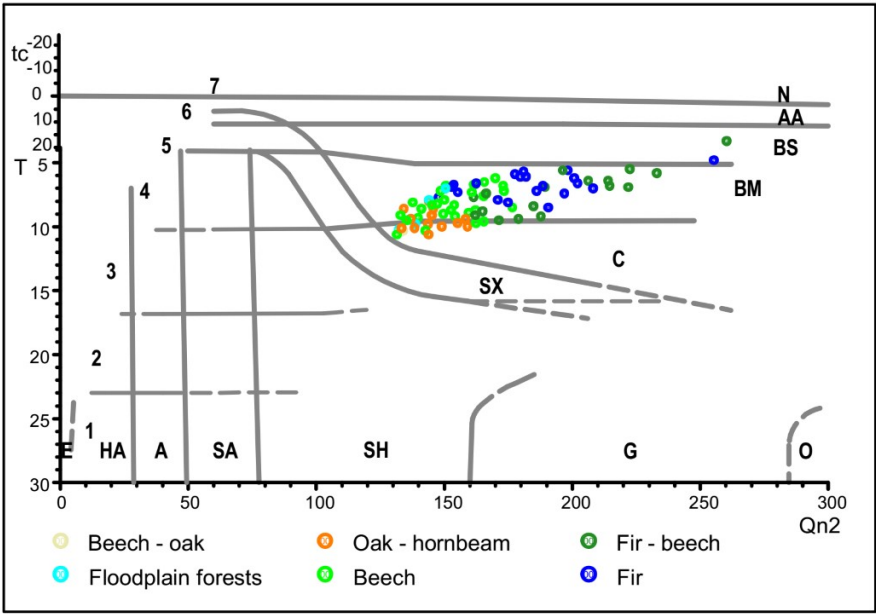

e)

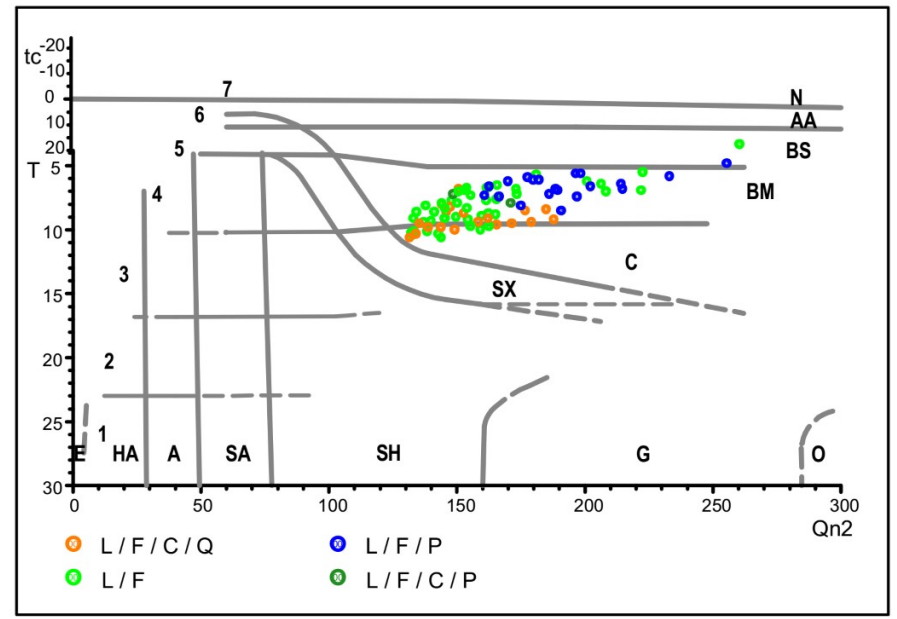

f)

Figure 7: Climagrams. e) B-W, vegetation classes according to PNV1974. f) B-W, vegetation complexes accordings to PNV2013. Legend: PNV1974, Potential Natural Vegetation map (Müller et al. 1974); PNV2013, Potential Natural Vegetation map (Reidl et al. 2013); RZF, Regional/Zonal forest map (Forstliche Versuchs- und Forschungsanstalt BadenWürttemberg 1997); C, Carpinion betuli; Q, Quercion roboris; L, Luzulo-Fagion; F, Fagion sylvaticae; P, Piceion abietis; tc, mean temperature of warmest month; T, annual mean temperature; Qn2, aridity/humidity index; E, Eremic; HA, Hyperarid; A, Arid; SA, Subarid; SH, Subhumid; SX, Subxeric; C, Colline; BM, Boreo-Montane; BS, Boreo-Subalpine; AA, Arctic-Alpine; N, Nival; G, Guinean; O, Ombrophilous; 1, Very hot; 2, Hot; 3, Temperate; 4, Cool; 5, Cold; 6, Very cold; 7, Nival. Climagram after Defaut (2015), slightly modified; vegetational and climatic data: see text.

\subsection{Baden-Württemberg's phytoclimatic stages compared to vegetation belts}

Stations with submontane and montane vegetation belts are comprehensively included in BoreoMontane stage, while stations of lowland-colline and altimontane belts are partly represented in the Boreo-Montane stage, partly in Colline and Boreo-Subalpine stages, respectively (Figure 8a). In particular, $55.6 \%$ of the stations of lowland-colline belts are in the Colline stage and $44.4 \%$ are in the Boreo-Montane stage. One of the three stations of the altimontane belt falls in the Boreo-Montane stage, the other two fall in the Boreo-Subalpine stage.

The RZF map (Forstliche Versuchs- und Forschungsanstalt 1997), establishes five elevation belts that are not phytosociologically based (Reidl et al. 2013). The five elevation belts are as follows: Lowland, Colline, Paenemontane, Submontane and Montane. While lowland and colline are split in two belts, this map does not recognize the altimontane belt. As shown in Figure 8b, weather stations of lowland belt are completely included in the Colline stage and those of paenemontane belt are completely included in Boreo-Montane stage. Submontane and montane belts are nearly completely (with $96 \%$ and $94.4 \%$ respectively) included in the Boreo-Montane stage. Few stations (5.6\%) of the montane belt fall in Boreo-Subalpine stage; most likely they are in the altimontane belt but are not recognized by the RZF map due to being too small or not useful for the map purposes. The Colline belt, is instead partly in BoreoMontane stage (64.3\%), and partly in Colline stage $(35.7 \%)$. As in the case of lowland-colline belt of the PNV2013 map, the RZF colline belt and phytoclimatic stages do not agree on the boundary that falls into colline vegetation belt.

\subsection{Emilia-Romagna's phytoclimatic stages compared to vegetation belts (1961-1990 and 1991-2005)}

As for Baden-Württemberg, phytoclimatic stages of Emilia-Romagna were also compared to the elevation belts as expressed by the vegetation. In addition, datasets related to the two series 1961-90 and 1991-2005 were compared. Data for both series are included in 34 meteorological stations. Weather stations in each belt of regional phytoclimatic map and Defaut's stages have been used. RPM recognizes 


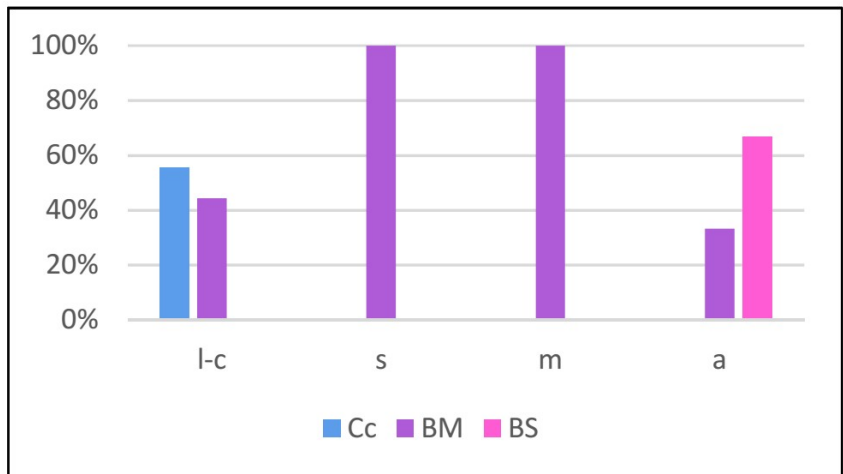

a)

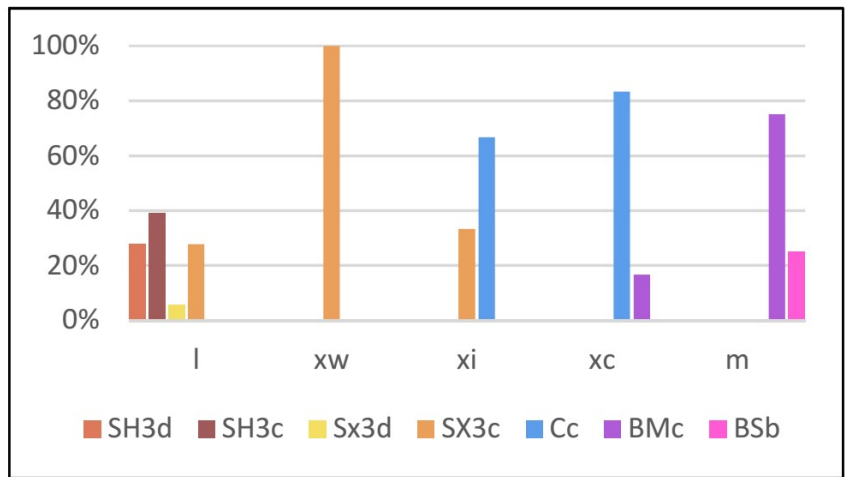

c)

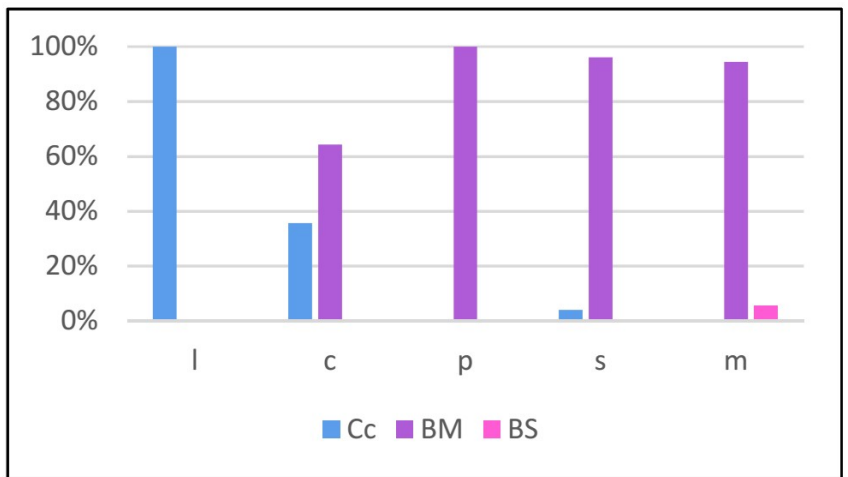

b)

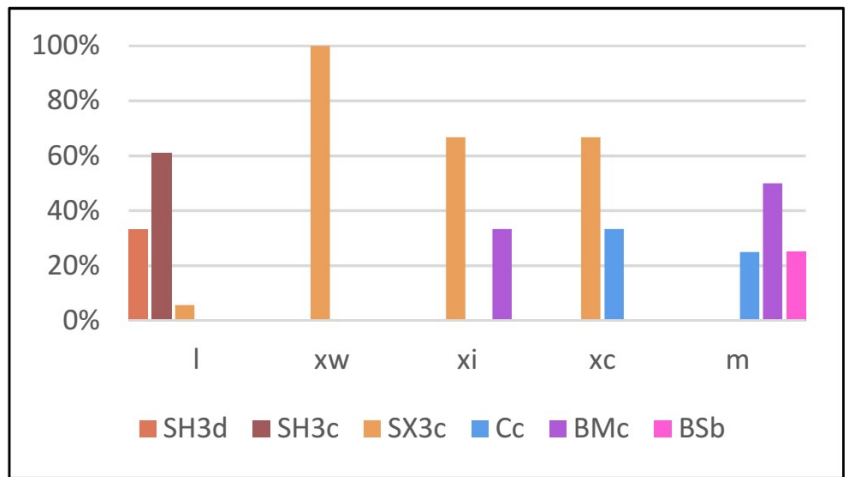

d)

Figure 8: Occurrence of stations and vegetation in phytoclimatic stages: a) Baden-Württemberg (B-W), PNV2013 belts; b) B-W, RZF belts. c) Emilia-Romagna (E-R), 1961-1990; d) E-R, 1991-2005. Legend: PNV2013, Potential Natural Vegetation map (Reidl et al. 2013); RZF, Regional/Zonal forest map (Forstliche Versuchs- und Forschungsanstalt BadenWürttemberg 1997); Belts: I, lowland; c, colline; p, paenemontane, s, submontane; m, montane; a, altimontane; I, lowland; xw, warm submediterranean; xi, intermediate submed.; xc, cool submed. Stages: SH3d, Subhumid temperate continental; SH3c, Subhumid temperate suboceanic; SX3d, Subxeric temperate continental; SX3c,Subxeric temperate suboceanic; C, Colline; BM, Boreo-Montane; BS, Boreo-Subalpine. Sources of vegetational and climatic data: see text.

different belts and sectors of the Apennine vegetation using a floristic (phytosociological) and biogeographical approach.

For the period 1961-1990 (Figure 8c), E-R's stations are classified as following (percentages rounded):

- Lowland (Po plain) stations: 39\% fall in SH3c, 28\% in SH3d, 28\% in SX3c, 6\% in SX3d;

- Warm submediterranean stations: $100 \%$ fall in SX3c;

- Intermediate submediterranean stations: $67 \%$ fall in $\mathrm{Cc}, 33 \%$ in SX3c;

- Cool submediterranean stations: $83 \%$ fall in Cc, $17 \%$ in BMc;
- Montane stations: $75 \%$ fall in BMc, $25 \%$ in BSb.

For the period 1991-2005 (Figure 8d), E-R's stations are classified as following (rounded percentages):

- Lowland (Po plain) stations: 61\% fall in SH3c, 33\% in SH3d, 6\% in SX3c;

- Warm submediterranean stations: $100 \%$ fall in SX3c;

- Intermediate submediterranean stations: $67 \%$ fall in SX3c, 33\% in BMc;

- Cool submediterranean stations: $67 \%$ fall in SX3c, $33 \%$ in Cc;

- Montane stations: $50 \%$ fall in BMc, $25 \%$ in Cc, $25 \%$ in BSb. 


\subsection{Spatial distribution of phytoclimatic stages}
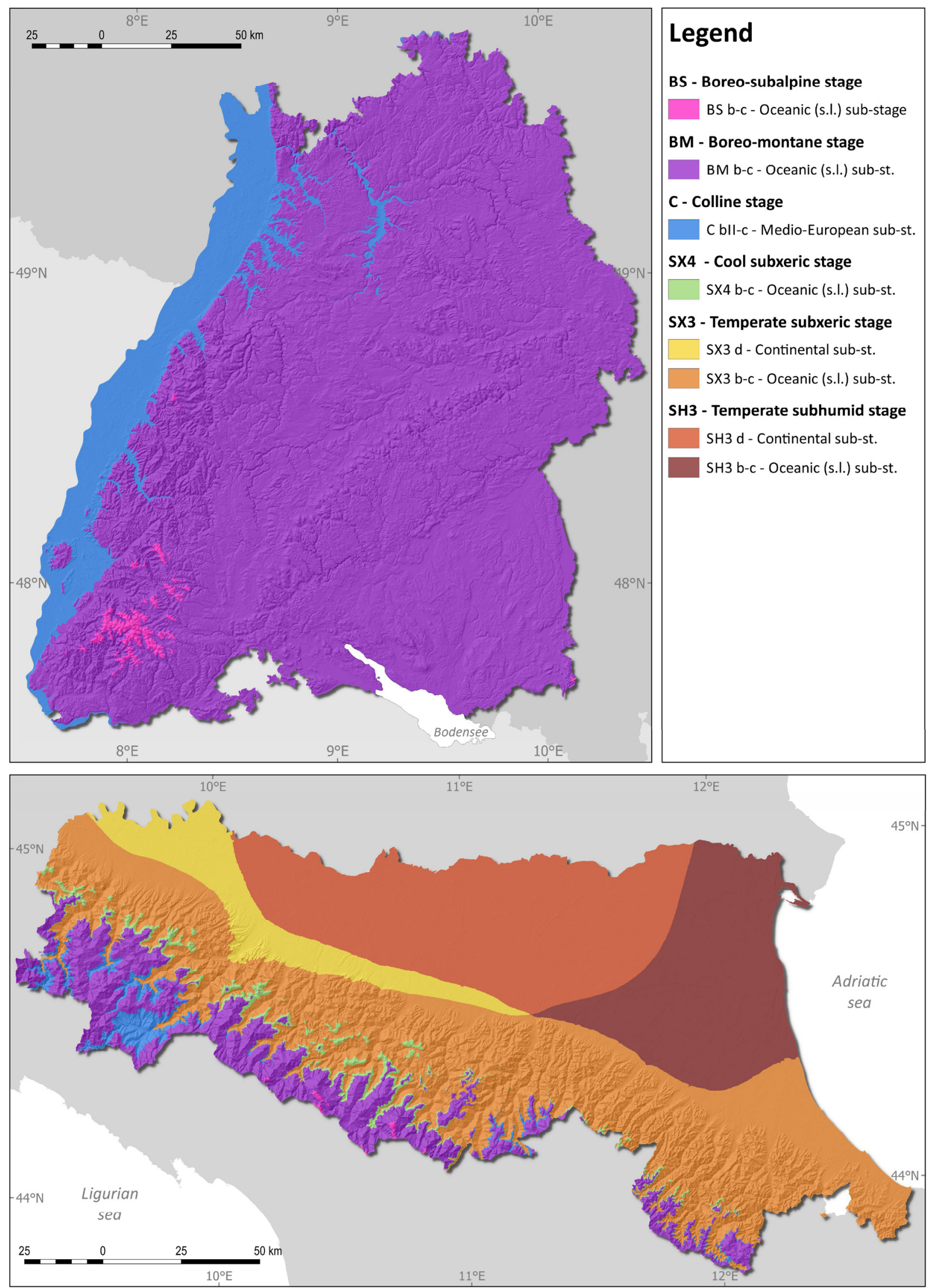

Figure 9: Maps of phytoclimatic stages in Baden-Württemberg (above) and Emilia-Romagna (below). Sources: EUDEM by Copernicus - European Union; (CGeoBasis-DE/BKG2015; Istituto Nazionale di Statistica (ISTAT); Regione EmiliaRomagna. Sources of climatic data: see text. Geodatabase and maps created by the author. 
Table 4: Area (percentage) of phytoclimatic stages in Baden-Württemberg and Emilia-Romagna.

\begin{tabular}{|l|l|l|}
\hline Stage & B-W & E-R \\
\hline BSb-c & 0.6 & 0.1 \\
\hline BMb-c & 88.6 & 12.1 \\
\hline CbII-c & 10.8 & 2 \\
\hline SX4b-c & & 1.6 \\
\hline SX3c & & 39.9 \\
\hline SX3d & & 6.9 \\
\hline SH3d & & 22.4 \\
\hline SH3c & & 14.9 \\
\hline
\end{tabular}

Phytoclimatic stages, their spatial distribution and their extension in $\mathrm{B}-\mathrm{W}$ and $\mathrm{E}-\mathrm{R}$ are illustrated on the maps in Figure 9 and in Table 4.

\subsection{Tentative phytoclimatic map of Emilia- Romagna}

The map in figure 10 represents a tentative effort to include the vegetation and climate relationship of $\mathrm{E}-\mathrm{R}$ in a larger framework, and to make possible a comparison between regional and continental climate/vegetation. Phytoclimatic units shown on the map are (other than stages and sub-stages) sub-units called sub-belts and sectors. Sub-belts are altitudinal subdivisions determined principally by temperature. Sub-belts are based on quarters of temperature classes. The quarter of temperature class was chosen after visual comparison to vegetation maps, trial and error and expert judgment. Quarters are named by roman numerals from warmer (I) to

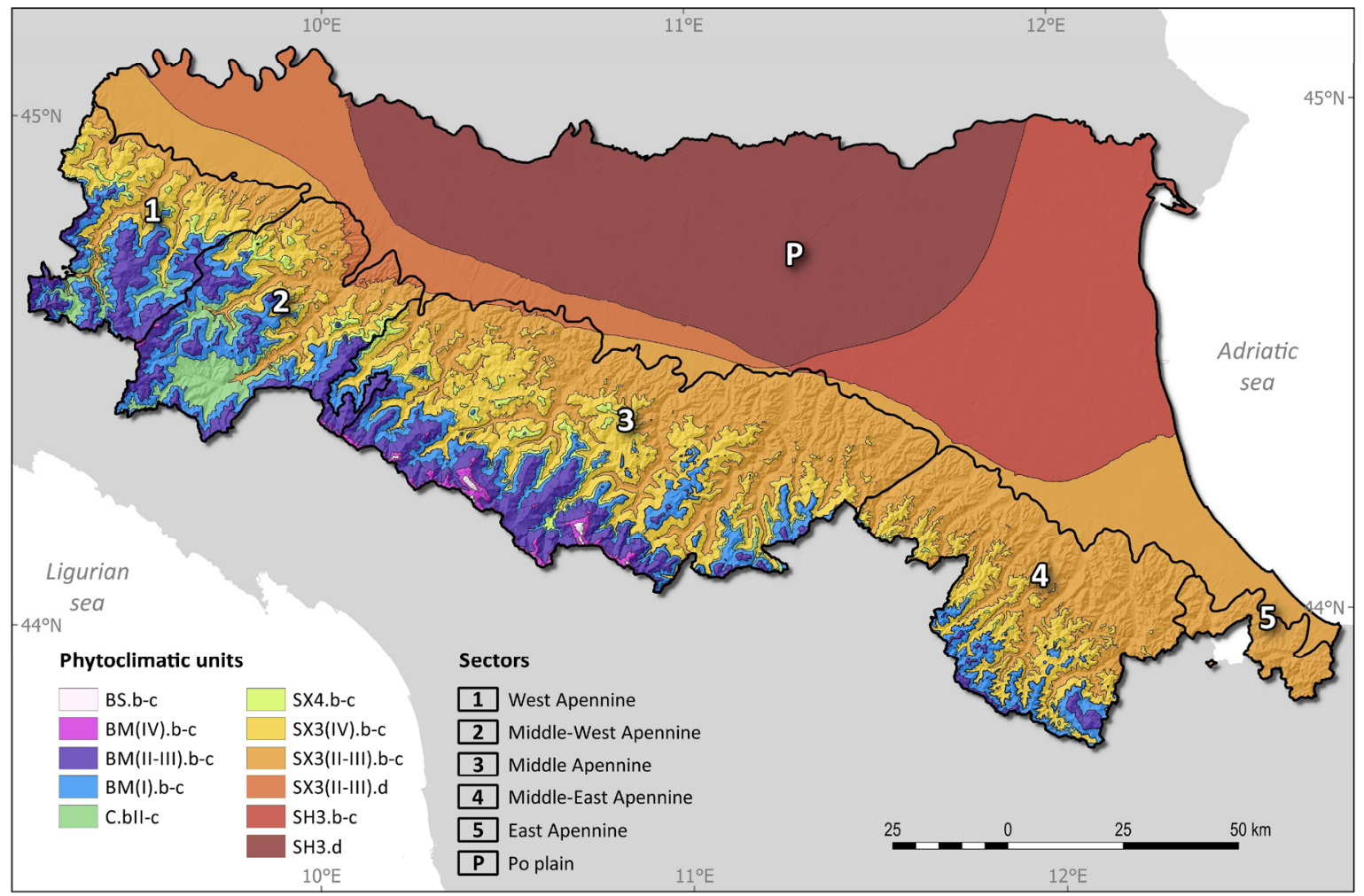

Figure 10: Map of phytoclimatic units in Emilia-Romagna (see Table 5 for full name of units). Sources: EU-DEM by Copernicus - European Union; Istituto Nazionale di Statistica (ISTAT); Regione Emilia-Romagna. Ubaldi et al. (1996), modified. Sources of climatic data: see text. Geodatabase and maps created by the author. 
colder (IV). Sectors are determined by continentality (expressed by distance from Adriatic Sea) and by biogeographical distribution of some plant species, some vegetation associations and their vicariants. Phytoclimatic stages and sub-stages are those of the map in Figure 9, while subdivisions and vegetation types were modified after Ubaldi et al. (1996). Further data from Ferrari (1997), Piccoli (1997), Puppi Branzi (1997) and Tomaselli (1997).

Table 5 lists phytoclimatic map units. The table shows unit names and their abbreviated formulae.

Table 5: Phytoclimatic units in Emilia-Romagna. Colours are the same as in Fig. 10.

\begin{tabular}{|c|c|c|c|}
\hline Phytoclimatic stage/sub-stage & $\begin{array}{ll}\text { Sub-belt } & \text { (if } \\
\text { present) } & \end{array}$ & Sector & Formula \\
\hline \multicolumn{4}{|l|}{ AXERIC PHYTOCLIMATE } \\
\hline \multicolumn{4}{|l|}{ BOREO-SUBALPINE STAGE (BS) } \\
\hline Oceanic sub-stage (BS b) & - & Middle Apennine (3) & $\mathrm{BSb}(3)$ \\
\hline \multicolumn{4}{|l|}{ BOREO-MONTANE STAGE (BM) } \\
\hline \multirow[t]{12}{*}{ Sub-oceanic sub-stage (BM b-c) } & \multirow[t]{4}{*}{ IV. upper } & 1. Western Apennine & BMb-c (IV.1) \\
\hline & & 2. Middle-Western Apennine & $\mathrm{BMb}-\mathrm{c}(\mathrm{IV} .2)$ \\
\hline & & 3. Middle Apennine & BMb-c (IV.3) \\
\hline & & 4. Middle-Eastern Apennine & BMb-c (IV.4) \\
\hline & \multirow[t]{4}{*}{ II-III. middle } & 1. Western Apennine & BMb-c (II-III.1) \\
\hline & & 2. Middle-Western Apennine & BMc (II-III.2) \\
\hline & & 3. Middle Apennine & BMc (II-III.3) \\
\hline & & 4. Middle-Eastern Apennine & BMc (II-III.4) \\
\hline & \multirow[t]{4}{*}{ I. lower } & 1. Western Apennine & $\mathrm{BMc}(\mathrm{I} .1)$ \\
\hline & & 2. Middle-Western Apennine & BMc (I.2) \\
\hline & & 3. Middle Apennine & BMc (I.3) \\
\hline & & 4. Middle-Eastern Apennine & BMc (I.4) \\
\hline \multicolumn{4}{|l|}{ COLLINE STAGE ( C ) } \\
\hline \multirow[t]{4}{*}{ Sub-oceanic sub-stage (C bll-c) } & \multirow[t]{4}{*}{-} & 1. Western Apennine & Cbll-c (1) \\
\hline & & 2. Middle-Western Apennine & Cbll-c (2) \\
\hline & & 3. Middle Apennine & Cbll-c (3) \\
\hline & & 4. Middle-Eastern Apennine & Cbll-c (4) \\
\hline \multicolumn{4}{|l|}{ SUBXERIC PHYTOCLIMATE } \\
\hline \multicolumn{4}{|l|}{ COOL SUBXERIC STAGE (SX 4) } \\
\hline \multirow[t]{4}{*}{ Sub-oceanic sub-stage (SX4 b-c) } & \multirow[t]{4}{*}{-} & 1. Western Apennine & SX4.b-c (1) \\
\hline & & 2. Middle-Western Apennine & SX4.b-c (2) \\
\hline & & 3. Middle Apennine & SX4.b-c (4) \\
\hline & & 4. 4. Middle-Eastern Apennine & SX4.b-c (4) \\
\hline \multicolumn{4}{|c|}{ TEMPERATE SUBXERIC STAGE (SX 3) } \\
\hline \multirow[t]{4}{*}{ Sub-oceanic sub-stage (SX3 b-c) } & \multirow[t]{4}{*}{ IV. upper } & 1. Western Apennine & SX3.b-c (IV.1) \\
\hline & & 2. Middle-Western Apennine & SX3.b-c (IV.2) \\
\hline & & 3. Middle Apennine & SX3.b-c (IV.3) \\
\hline & & 4. Middle-Eastern Apennine & SX3.b-c (IV.4) \\
\hline
\end{tabular}




\begin{tabular}{|c|c|c|c|}
\hline & \multirow[t]{4}{*}{ II-III. lower } & 1. Western Apennine & SX3.b-c (IV.1) \\
\hline & & 2. Middle-Western Apennine & SX3.b-c (IV.2) \\
\hline & & 3. Middle Apennine & SX3.b-c (IV.3) \\
\hline & & 4. Middle-Eastern Apennine & SX3.b-c (IV.4) \\
\hline & & 5. Eastern Apennine & \\
\hline & & P. Plain & \\
\hline Continental sub-stage (SX3 d) & II-III. lower & 2. Middle-Western Apennine & SX3c (II.1) \\
\hline & & 3. Middle Apennine & \\
\hline & & P. Plain & SX3c (II.5) \\
\hline XERIC PHYTOCLIMATE & & & \\
\hline TEMPERATE SUBHUMID STAGE & & & \\
\hline sub-oceanic sub-stage ( $\mathrm{SH} 3 \mathrm{c})$ & - & P. Plain & SH3(P).b-c \\
\hline continental sub-stage $(\mathrm{SH} 3 \mathrm{~d})$ & - & P. Plain & $\mathrm{SH} 3(\mathrm{P}) \cdot \mathrm{d}$ \\
\hline
\end{tabular}

Table 6 is an attempt to relate each phytoclimatic unit to the zonal/etageal vegetation. The table is tentative and far from complete since quantity and quality of data are not homogeneous for the entire study area.

Table 6: Phytoclimatic units of Emilia-Romagna and their zonal/etageal vegetation. See Table 5 for full name of phytoclimatic units.

\begin{tabular}{|l|l|}
\hline Units & Reference Syntaxa and communities* \\
\hline BS(3).b-c & Communities of Loiseleurio procumbentis-Vaccinietea microphylli Eggler ex Schubert 1960 \\
\hline BM(IV.1-2).b-c & $\begin{array}{l}\text { Vaccinio myrtilli-Piceetea abietis Br.-BI. in Br.-BI., Sissingh \& Vlieger 1939. Calamagrostio } \\
\text { villosae-Pinetum uncinatae rostratae Gentile 1995 }\end{array}$ \\
\hline BM(IV.3).b-c & Ecotonal belt between montane beech woods and subalpine communities \\
\hline BM(II-III.1).b-c & $\begin{array}{l}\text { Montane belt s.s. Fagetalia sylvaticae Pawl. 1928: a) upper elevation: Melico nutantis- } \\
\text { Fagetum Ubaldi et al. 1996 (nomen nudum); b) lower elevation: Seslerio argenteae- } \\
\text { Fagetum Ubaldi et al. 96 (nomen nudum) }\end{array}$ \\
\hline BM(II-III.2).b-c & $\begin{array}{l}\text { Montane belt s.s. Fagetalia sylvaticae Pawl. 1928: a) upper elevation: Trochiscantho- } \\
\text { Fagetum Gentile 1974 subass festucetosum altissimae; b) lower elevation: Trochiscantho- } \\
\text { Fagetum Gentile 1974 subass leucojetosum verni }\end{array}$ \\
\hline BM(II-III.3).b-c & $\begin{array}{l}\text { Montane belt s.s. Fagetalia sylvaticae Pawl. 1928: a) upper elevation: Gymnocarpio- } \\
\text { Fagetum (Ubaldi et Speranza 1985) Ubaldi 1993-1995; b) lower elevation: Saniculo- } \\
\text { Fagetum (Ubaldi et Speranza 1985) Ubaldi 1993-1995 }\end{array}$ \\
\hline BM(II-III.4).b-c & $\begin{array}{l}\text { Montane belt s.s. Fagetalia sylvaticae Pawl. 1928: a) upper elevation: Galeopsi-Fagetum } \\
\text { (Ubaldi et Speranza 1985) Ubaldi 1993-1995 (=Polygonato verticillati-Fagetum Ubaldi et } \\
\text { Speranza 1985 nom. inv.); b) lower elevation: Aceri platanoidis-Fagetum (Ubaldi et } \\
\text { Speranza 1985) Ubaldi 1993-1995 }\end{array}$ \\
\hline
\end{tabular}




\begin{tabular}{|c|c|}
\hline $\begin{array}{l}\text { BM(I.1-2).b-c; } \\
\text { perhaps in part } \\
\text { SX4(1-2).b-c }\end{array}$ & $\begin{array}{l}\text { Submontane belt s.s. Quercetalia pubescenti-petraeae Klika 1933: a) all aspects: Ostryo- } \\
\text { Aceretum opulifolii (Ubaldi et al. 1987) Ubaldi et al. 1993-1995 (west emilian race - } \\
\text { submontane form); b) drier aspects and degraded soils: communities with Quercus } \\
\text { pubescens }\end{array}$ \\
\hline $\mathrm{BM}(\mathrm{I} \cdot 3) \cdot \mathrm{b}-\mathrm{c}$ & $\begin{array}{l}\text { Submontane belt s.s. Data in literature are related to slopes protected by the main } \\
\text { Apennine's ridge. Quercetalia pubescenti-petraeae Klika 1933: a) warmer aspects: Ostryo- } \\
\text { Aceretum opulifolii (Ubaldi et al. 1987) Ubaldi et al. 1993-1995 (central emilian race - } \\
\text { submontane form); b) cooler aspects: Dryopterido-Ostryetum carpinifoliae Ubaldi et al. } \\
\text { 1993-1995 }\end{array}$ \\
\hline $\begin{array}{l}\text { SX3(IV.1).b-c; } \\
\text { SX3(II-III.1).b-c; } \\
\text { perhaps in part } \\
\text { SX4(1).b-c }\end{array}$ & $\begin{array}{l}\text { Data in literature consider together lower and upper submediterranean belts: a) warmer } \\
\text { aspects: communities with Quercus pubescens (or Q. pubescens and Q. cerris) and } \\
\text { Cotynus coggygria; b) cooler aspects: communities with } Q \text {. pubescens (or Q. pubescens } \\
\text { and Q. cerris) and Corylus avellana }\end{array}$ \\
\hline $\begin{array}{l}\text { SX3(IV.2).b-c; } \\
\text { SX3(II-III.2).b-c; } \\
\text { perhaps in part } \\
\text { SX4(2).b-c }\end{array}$ & $\begin{array}{l}\text { Data in literature consider together lower and upper submediterranean belts: a) Ostryo- } \\
\text { Aceretum opulifolii (Ubaldi et al. 1987) Ubaldi et al. 1993-1995 (west emilian race - } \\
\text { without submontane species); b) in the lower belt, communities with predominance of } \\
\text { Quercus pubescens }\end{array}$ \\
\hline $\begin{array}{l}\text { SX3(IV.3).b-c; } \\
\text { perhaps } \\
\text { SX4(3).b-c }\end{array}$ & $\begin{array}{l}\text { Upper (cool) submediterranean belt. Quercetalia pubescenti-petraeae Klika 1933: a) } \\
\text { warmer aspects: Knautio-Quercetum pubescentis (Ubaldi 1980) Ubaldi et al. 1993 } \\
\text { (submontane form); b) cooler aspects: Ostryo-Aceretum opulifolii (Ubaldi et al. 1987) } \\
\text { Ubaldi et al. 1993-1995 (central emilian race-submontane form) }\end{array}$ \\
\hline SX3(IV.4).b-c & $\begin{array}{l}\text { Upper (cool) submediterranean belt. Quercetalia pubescenti-petraeae Klika 1933: a) } \\
\text { warmer aspects: Knautio-Quercetum pubescentis (Ubaldi 80) Ubaldi et al. 93 } \\
\text { (submontane form); b) cooler aspects: Ostryo-Aceretum opulifolii (Ubaldi et al. 1987) } \\
\text { Ubaldi et al. 1993-1995 (Romagna race - submontane form) }\end{array}$ \\
\hline SX3(II-III.3).b-c & $\begin{array}{l}\text { Lower (warm) submediterranean belt. Quercetalia pubescenti-petraeae Klika 1933: a) } \\
\text { mesic and warmer aspects: Knautio-Quercetum pubescentis; b) cooler aspects: Ostryo- } \\
\text { Aceretum opulifolii (central emilian race - colline form) }\end{array}$ \\
\hline SX3(II-III.4).b-c & $\begin{array}{l}\text { Lower (warm) submediterranean belt. Quercetalia pubescenti-petraeae Klika 1933: a) } \\
\text { mesic and warmer aspects: Knautio-Quercetum pubescentis; b) cooler aspects: Ostryo- } \\
\text { Aceretum opulifolii (Romagna race - colline form) }\end{array}$ \\
\hline SX3(II-III.5).b-c & $\begin{array}{l}\text { Sublittoral warm submediterranean belt. Quercetalia pubescenti-petraeae Klika 1933: a) } \\
\text { all aspects: Clematido flammulae-Quercetum pubescentis Ubaldi \& Rondini in Ubaldi et al. } \\
1995 \text { (Ubaldi et al., 1984, Ubaldi, 1988; Ubaldi et al., 1995, Ubaldi, 1995; b) extrazonal: } \\
\text { Ostryo-Aceretum opulifolii (Romagna race - colline form) }\end{array}$ \\
\hline $\begin{array}{l}\text { SX3(II-III.P).b-c; } \\
\text { SX3(II-III.P).d; } \\
\text { SH3(P).d }\end{array}$ & $\begin{array}{l}\text { Communities of Carpinion betuli Issler 1931: Querco-Carpinetum boreoitalicum (Pignatti, } \\
\text { 1953). In southeastern coastal areas, perhaps also transitional communities of } \\
\text { Quercetalia pubescenti-petraeae Klika } 1933 \text { and Quercetalia ilicisBr.-Bl. ex Molinier 1934/ } \\
\text { Fraxino orni-Quercion ilicis Biondi, Casavecchia et Gigante } 2003\end{array}$ \\
\hline $\mathrm{SH} 3(\mathrm{P}) \cdot \mathrm{b}-\mathrm{c}$ & $\begin{array}{l}\text { Communities of Carpinion betuli Issler 1931: Querco-Carpinetum boreoitalicum (Pignatti, } \\
\text { 1953). On coastal dunes, communities of a) Quercetalia pubescenti-petraeae Klika 1933: } \\
\text { Clematido flammulae-Quercetum pubescentis Ubaldi \& Rondini in Ubaldi et al. } 1995 \\
\text { (Ubaldi et al., 1984, Ubaldi, 1988; Ubaldi et al., 1995, Ubaldi, 1995; b) Quercetalia ilicis } \\
\text { Br.-Bl. ex Molinier 1934/ Fraxino orni-Quercion ilicis Biondi, Casavecchia et Gigante 2003: } \\
\text { Vincetoxico-Quercetum ilicis Gamper et Al. 2008; c) transitional communities }\end{array}$ \\
\hline
\end{tabular}

* (Ubaldi et al. 1996; Ferrari 1997; Biondi et al. 2006; Gamper et al. 2008). 


\section{Discussion and Conclusions}

\subsection{Patterns of weather stations as plotted in the Defaut's climagram}

Weather stations of B-W and E-R, plotted according to their climatic parameters on the climagram, are shown in Figures 7a-f.

Figure $7 a$ shows $\mathrm{B}-\mathrm{W}$ and $\mathrm{E}-\mathrm{R}$ weather stations plotted together. Of note is the partial overlapping of the point clouds of the two study areas. In the overlapped areas, it is expected that both areas have similar vegetation and share the same ecological (climatological) requirements. Emberger (1939) speaks about "equivalent or homologue" vegetation. For instance, in Bad Herrenalb (B-W) and in Campigna (E-R) climatological indexes have similar values. The temperature value (T) is $8.5^{\circ} \mathrm{C}$ for Bad Herrenalb and $8.6^{\circ} \mathrm{C}$ for Campigna, aridity/ humidity (Qn2) is 190.6 for the former and 189.7 for the latter. Value of continentality (tc-tf) is $16.8^{\circ} \mathrm{C}$ in Bad herrenalb, and $16.9^{\circ} \mathrm{C}$ in Campigna. According to DSPS both the stations are in Boreo-Montane stage, suboceanic sub-stage (BM b-c). Therefore, according to DSPS, potential, climatically determined natural vegetation in both stations should be represented by beech forest communities, namely: Luzulo Fagion on acid soils, Fagion silvaticae on weakly acidic and neutral soils, Cephalanthero-Fagion on basic soils. In the "map of the natural vegetation of Europe" (Bohn et al. 2000/2003), in both Bad Herrenalb and Campigna, the expected natural vegetation is montane-altimontane mesophytic deciduous broadleaved and mixed coniferous-broad-leaved forest, with Fagus sylvatica and partly with Abies alba. Note that sites in B-W and E-R that share similar phytoclimates host different syntaxa, i.e. homologue climatic vegetation types that consist of generally different species. Likely, this fact is mainly due to the different biological histories of such sites (see Schroeder 1998).

Climagram in Figure $7 \mathrm{~b}$ shows E-R weather stations. $\mathrm{E}-\mathrm{R}$ weather stations are not evenly distributed. Note the lacking of points in the upper Boreo-Montane stage. In the Boreo-Subalpine stage there is only one point, the station on top of Mount Cimone (the highest mountain of Northern Apennine, 2165 masl), although a long ridge and several summits are supposedly in such a stage. Distribution of points forms a cloud going from lower-left to upperright, indicating an inverse proportionality between warmth and moisture. Outside this pattern is the only site in Boreo-Subalpine stage, due to lower precipitation at a higher altitude. Perhaps this fact might be due to the location of Mount Cimone, as an isolated peak north of the main ridge (Vianelli 1998), but the lack of other high altitude stations prevents the confirmation of such a hypothesis. According to Ozenda (2002) inversion of precipitation trends is observed in high mountains at both higher and lower altitudes (e.g. in the Alps above 3000 or 4000 masl). In Mediterranean mountains, the precipitation peak occurs at middle altitudes (Poli 1965; Rivas-Martinez 1987, in Ozenda 2002). Lowland sites tend to group in the climagram. Such sites are better distinguished by thermal continentality.

B-W climatological stations are more evenly distributed than those of E-R (Figure 7c-f). The points form a nearly continuous cloud from Colline to Boreo-Subalpine stage. However, a gap exists between the two points in BS stage and the wettest points in BM stage. As in E-R, also in B-W, warmth is inversely proportional to moisture, but the trend from warmer and drier sites to colder and moister appears less accentuated. Furthermore, the colder stations $\left(\mathrm{T} 5.5-5.8^{\circ} \mathrm{C}\right.$ ) of the montane belt are aligned near the limit between BM and BS stages while their moisture (Qn2) varies from around 180 to 230 .

Figure $7 \mathrm{c}$ and $7 \mathrm{~d}$ illustrate, respectively, the weather stations plotted with colours according to the belts of PNV2013 and RZF maps. The different colours of plotted points show clearly that boundaries between lowland-colline, submontane and montane belts go from upper-left to lower-right. Both B-W climagrams, based on RZF and PNV2013 show the same pattern of altitudinal belts (except for the boundary between lowland and colline belt in the RZF climagram which is somewhat parallel to boundary C - BM). Such a pattern could likely be due to the fact that higher moisture can compensate for higher temperature (and a higher evapotranspiration rate). Unfortunately, points of E-R are too few to permit comparison and even to discern similar (or different) patterns. 
For comparison, weather stations of B-W were also plotted with colours according to vegetation classes of the Potential Natural Vegetation map of 1974 (also PNV1974) (Müller et al. 1974) and according to the vegetation complexes of PNV2013 (Reidl et al. 2013), as shown, respectively, in Figure 7e and Figure $7 f$.

In PNV1974, beech-oak forests (two points) are found in C stage, in the warmest and driest sites. Oak-hornbeam forests are found in warm and dry sites, partly in C stage, partly in BM stage. Beech forests are found mostly in the warmest sites of BM stage, and few in sites of $C$ stage. Fir-beech forests are found in BM stage (except one in BS stage) from warm and moderately moist sites to cool and wet sites. Fir forests are located in BM stage (except one in BS stage), in sites with intermediate moisture between beech and fir-beech forests.

In PNV2013, complexes of Luzulo-Fagion - Fagion - Carpinion - Quercion are widely distributed in sites of $C$ and BM stages. They occur from warmest and driest sites to moderately wet and cool sites. Complexes of Luzulo-Fagion - Fagion sylvaticae are found mostly in BM stage, relatively few in C stage and one in BS stage. They occur in sites throughout the entire range of temperature and moisture. Complexes of Luzulo-Fagion - Fagion - Piceion are located in BM stage (except one in BS stage), in sites with intermediate to high moisture. Finally, complexes of Luzulo-Fagion - Fagion - Carpinion Piceion (two points) are located in dry and medium moist sites in BM stage.

The results indicate that the Defaut's climagram is also a useful tool to study vegetation patterns in situations in which vegetation types (or altitudinal belts) do not fit perfectly with phytoclimatic stages. The climagram shows ecological position and relationships among different vegetation types. Despite being based on phytosociological syntaxa, this study shows that it is also useful in ecological studies based on other criteria, e.g. forestry vegetation types. Perhaps, use of climagram may be also helpful to better characterize vegetation types and help to classify them in high ranks.

It is important to note that DSPS is not a fixed system. It is open to improvement with the input of more and better vegetation and climate data. It is also possible to subdivide existing classes for more detailed investigations, as shown, e.g. regarding E-R phytoclimatic units.

\subsection{Emilia-Romagna's phytoclimatic stages and vegetation belts in 1961-1990 and 1991-2005 periods.}

Compared to the 1961-1990 dataset, the 1991-2005 dataset indicate a general increase in dry and warm conditions (see Fig. 8c-d). In particular, in lowland increase the stations in $\mathrm{SH} 3$ stage, and only one station remains in the SX3 stage. In Appennine stations, the pattern of change is similar, with an increase of drier and warmer conditions. In particular, in the warm and intermediate submediterranean belts appeared $\mathrm{SH} 3 \mathrm{c}$ stage; in intermediate submediterranean belt BMc stage disappeared and SX3c stage increased; in the cool submediterranean stage appeared SX3c stage and BMc stage disappeared; in montane belt, BMc stage decreased and Cc stage appeared.

Although based on limited data, this study indicates a general movement of climate patterns toward drier and warmer conditions.

If European vegetation where in equilibrium with the climate, DSPS could be used to predict possible transformations in the distribution of vegetation caused by climate change. If the assumption were not to be verified, the DSPS model could still be useful for predicting the relative relationship between temperature, aridity and plant formations in general. It is important to note that some studies indicate that European vegetation, depleted by the last glacial period, is not in equilibrium with the climate. For instance, according to Svenning \& Skov (2004), the range of European trees species, is "strongly controlled by large-scale historical constraints, in addition to climate". Different species have different dispersion rates, and therefore different rates in occupying potential territory.

\subsection{Spatial distribution of phytoclimatic stages compared to existing vegetationbelts.}

Phytoclimatic stages are expressed by zonal climax vegetation, considered at the phytosociological unit level (at higher rank, as far as possible) (Defaut, 
2015). Therefore, conversely, phytoclimatic stages would predict zonal climax vegetation. However, a complete agreement between (bio)climatic and vegetation maps is not expected for many reasons. An initial challenge occurs due to their different nature and the different manner in which they are mapped. As noted by Perera (1968), "Vegetation and soils are concrete elements of the landscape; climate by definition has only statistical reality". Both climate and vegetation are complex and their approximate correlation also depends upon which factors are taken into account (Küchler 1967). Furthermore, it is difficult to match systematic and spatial hierarchies (Klijn 1997). Topoclimate, geomorphology, soils and successional stage are all factors that differentiate vegetation under the same macroclimate. A bioclimatic potential area might not be entirely occupied by a vegetation type because of historical or topo-edaphic factors. Conversely, topo-edaphic factors can permit a vegetation type to colonize unsuitable (macro)bioclimatic areas. Dispersal rates and biogeographical history also play a fundamental role. In addition, the quality and quantity of data influence the results of a study. The different vegetation maps used in this study have different scales. In these maps, vegetation was classified and mapped in different ways. Moreover, the vegetation mapped is a conceptual abstraction, because man modifies vegetation directly or indirectly through the disturbance of ecosystem processes, and also because completely intact natural vegetation, if it exists, is dynamic and subject to stochastics changes. Therefore, it is possible to say that phytoclimatic maps try to approximate the spatial distribution of a theoretical vegetation. Nevertheless, despite the above mentioned issues and concerns, phytoclimatic classifications retain their usefulness as conceptual and practical tools, as shown also by the numerous examples developed up to now by many researchers.

Table 7 compares the occurrence of high rank phytosociological syntaxa, as predicted by phytoclimatic stages, and potential natural vegetation of B-W and E-R as mapped in PNV2013 and RPM. Predicted syntaxa are those indicated by Defaut (1996) for Western and Southeastern Europe. For comparison, Middle East vegetation of stage SH3d was also included. Some clarifications are necessary regarding the syntaxa listed in the table. B-W column lists vegetation complexes of each stage, while E-R column lists names of major syntaxa for each stage. Due to the lack of data, vegetation types of acid soils are not given for $\mathrm{E}-\mathrm{R}$.

Expected potential vegetation in $\mathrm{B}-\mathrm{W}$ and $\mathrm{E}-\mathrm{R}$ substantially confirm vegetation predicted by phytoclimatic stages but exceptions are found in both study areas. In particular, in B-W, syntaxa of warmer stages seem to mix progressively with syntaxa of cooler stages. Communities of BoreoMontane stage (Luzulo-Fagion and Fagion sylvaticae) seem widespread in all stages. Complexes with the presence of Carpinion betuli and Quercion roboris (indicating Colline stage) diminish from the Colline to the Boreo-Montane stage. They are absent in the Boreo-Subalpine stage. Inversely, complexes with Piceion abietis are more diffuse in the BoreoSubalpine stage, diminish in the Boreo-Montane stage and are absent in the Colline stage. Other than the presence of a smooth gradient, this admixture might be due to the mapping method which considers complexes of vegetation, not single climatic climax associations.

In $E-R$, the first difference between predicted and expected vegetation relates to the Colline stage, where there are communities of Quercetalia pubescentis, predicted by Defaut's system only in the Temperate Subxeric stage. However, these communities are more mesophilous than typical communities of Quercetalia pubescentis dominated by Quercus pubescens. Note, according to Oberdorfer (1968), Nord-Apennines mesophylous woods on fresh, cool, mostly lime-poor soils are communities of Carpinion. Therefore, we could assume that in E-R, a Colline stage exists between the Boreo-Montane and the Temperate Subxeric stage.

The second difference relates to the (potential) presence of communities of Carpinion betuli in the Temperate Subxeric and Subhumid stages. This is due to the local "correction" (sensu Defaut, 1996) given by alluvial and ever moist soils of the Po plain. The third difference is the almost complete lack of Quercetalia ilicis communities in the Temperate Subhumid stage, except for some coastal areas. This fact is probably due in part to edaphic correction of alluvial moist soils and in part due to climatic factors 
not considered in the present analysis. Defaut (1996) observed that, in areas where natural vegetation is highly altered or degraded by humans, the climagram shows a warmer and drier climate than that indicated by the remaining (semi) natural vegetation. According to Box \& Fujiwara (2015), the lack of evergreen vegetation in areas like the Po plain could be due to absolute winter minimum temperature, below $-15^{\circ} \mathrm{C}$. Examples of sclerophyllous vegetation occur only in a narrow band along the coast. In such areas, complex factors such as maritime influence, dry coastal dunes and interdunal moist soils create a rich mosaic of ecological conditions including woods with Quercus ilex, Q. pubescens, Q. robur, Carpinus betulus and $C$. orientalis.
Phytoclimatic maps produced in this study were compared visually to PNV2013 and RPM maps. This comparison is based on expert judgment, due to the heterogeneity in the illustrated data and map scales.

The pattern of phytoclimatic units in B-W (Figure 9, above) seems controlled principally by the temperature decrease due to altitude. Continentality, increasing from west to east seems of lesser importance. Patterns shown by PNV2013's map vegetation belts and by DSPS map are similar. The Rhine river valley and the lower river Neckar valley are the warmest areas in B-W, classified as Planar-Colline belt by the PNV2013, Colline stage / Medio-European sub-stage (CbII-c) by DSPS.

Table 7: Comparison between predicted and potential vegetation as expressed by high rank syntaxa. B-W = BadenWürttemberg; E-R = Emilia-Romagna. Sources: see text.

\begin{tabular}{|c|c|c|c|}
\hline Stage & Predicted & B-W & $\mathrm{E}-\mathrm{R}$ \\
\hline BSb & $\begin{array}{l}\text { Vaccinio-Piceetalia } \\
\text { (Vaccinio-Piceetea) }\end{array}$ & $\begin{array}{l}\text { Luzulo-Fagion, Fagion } \\
\text { sylvaticae, Piceion abietis }\end{array}$ & $\begin{array}{l}\text { Seslerio-Pinion (Vaccinio- } \\
\text { Piceetea), Loiseleurio-Vaccinion } \\
\text { and Rhododendro-Vaccinion } \\
\text { (Loiseleurio-Vaccinietea) }\end{array}$ \\
\hline BMc & $\begin{array}{l}\text {-Montane belt s.s.: Luzulo- } \\
\text { Fagion, Fagion sylvaticae, } \\
\text { Cephalanthero-Fagion; } \\
\text {-Submontane belt with } \\
\text { colline species; } \\
\text {-Upper belt with Abies, } \\
\text { Picea, Larix, Pinus uncinata } \\
\text { and Acer pseudoplatanus. }\end{array}$ & $\begin{array}{l}\text { Luzulo-Fagion, } \\
\text { sylvaticae, Quercion roboris, } \\
\text { Carpinion betuli, Piceion abietis }\end{array}$ & $\begin{array}{l}\text { Fagetalia } \\
\text { sylvaticaeCalamagrostio } \\
\text { villosae-Pinetum uncinatae } \\
\text { rostratae }\end{array}$ \\
\hline Cc & $\begin{array}{lr}\text { Quercion } & \text { robori-petraeae, } \\
\text { Genisto } & \text { germanicae- } \\
\text { Quercion, Fraxino-Carpinion }\end{array}$ & $\begin{array}{l}\text { Luzulo-Fagion and Quercion } \\
\text { roboris, Fagion sylvaticae and } \\
\text { Carpinion betuli }\end{array}$ & Quercetalia pubescentis; \\
\hline SX3c & $\begin{array}{l}\text { In Italy: Quercion } \\
\text { pubescenti-petraeae, } \\
\text { Ostryo-Carpinion } \\
\text { (Quercetalia pubescentis) }\end{array}$ & & Quercetalia pubescentis \\
\hline SX3d & $\begin{array}{l}\text { In Italy: Ostryo-Carpinion } \\
\text { (Quercetalia pubescentis) }\end{array}$ & & Carpinion betuli \\
\hline SH3d & $\begin{array}{l}\text { According to Defaut (1996) } \\
\text { only in Middle East: forests } \\
\text { with Quercus castanaefolia, } \\
\text { Parrotia persica, Carpinus } \\
\text { caucasica. }\end{array}$ & & Carpinion betuli \\
\hline SH3c & Quercetalia ilicis & & $\begin{array}{l}\text { Fraxino orni-Quercion ilicis } \\
\text { (Quercetalia ilicis), Carpinion } \\
\text { betuli }\end{array}$ \\
\hline
\end{tabular}


In the PNV2013, a large region around the lower river Neckar valley is classified as Planar-Colline, whereas in DSPS just the river valley is included in stage Cbll-c. Above the Cbll-c sub-stage, the DSPS map classifies the majority of the B-W's area as Boreo-montane stage / Oceanic (sensu lato) sub-stage (BM b-c). Note that the DSPS Boreo-montane stage includes, other than the montane (sensu stricto) belt, a lower (submontane) belt and an upper (altimontane) belt (Defaut 1996). PNV2013 differentiates these three belts. A difference between the DSPS and PNV2013 maps is the presence of a Boreo-subalpine stage/Oceanic (s.l.) sub-stage on the Schwarzwald summits, not mirrored by a subalpine belt in the PNV2013. The PNV2013's accompanying notes (Reidl et al. 2013) recognize the presence of subalpine vegetation complexes in the Feldberg area (the highest mountain of B-W, 1493 masl). However, these subalpine communities occur at special sites and are not considered zonal.

The pattern of phytoclimatic units in E-R (Figure 9, below and Figure 10) seems primarily controlled by temperature decrease and humidity increase due to altitude, and secondarily by continentality determined by distance from the Adriatic Sea.

A visual comparison of the phytoclimatic E-R's maps with the RPM, shows good agreement, especiallybetween spatial distribution of the montane and the two submediterranean belts. The Temperate (oceanic s.I.) subxeric stage/second-third quarters sub-belt "SX3(II-III).b-c" of this study has a similar distribution of the warm submediterranean belt of RPM. The Temperate (oceanic s.I.) subxeric stage/fourth quarter sub-belt "SX3(IV).b-c" of this study has a similar distribution of the cool submediterranean belt of RPM. A good agreement there is also shown between the montane belt (s.s.) of this study "Boreo-montane, oceanic s.l. stage/ second-third quarters sub-belt "BM(II-III).b-c" and the montane belt of RPM. Differences between the two maps are found principally in the following areas and belts:

- Po Plain: Comparison between phytoclimatic stages and vegetation zones of the plain is difficult. Indeed, due to the degradation (and lack) of (semi)natural vegetation in the plain, the RPM map uses a different approach than in the Apennines. To map plain zones, except for the northern coast, where relatively large tracts of seminatural vegetation remain, RPM map's authors have used some common species living in meadows at road edges as indicator species. These species were selected according to their reliance on a Mediterranean climate;

- Western Apennine: here RPM recognizes the presence of a submediterranean belt dominated by Quercus pubescens but it is not mapped. RPM considers submediterranean belts in western Apennine as an intermediate belt between warm and cool ones;

- Altimontane and subalpine belts: RPM does not map them;

- Submontane belt: the submontane belt of this study, i.e. Boreo-montane (oceanic s.l.) stage/ first quarter sub-belt "BM(I).b-c" shows a good agreement with the submontane belt of RPM in the west and central E-R. RPM does not map this belt in the central-eastern and eastern areas;

- Transitional sub-stages SX4 and Cbll-c: it is difficult to compare these units to RPM. SX4 (i.e. Cool subxeric, oceanic s.I., sub-stage) occurs on relief tops external to the main Apennine range, above the Temperate subxeric stage. RPM does not distinguish them from the cool submediterranean belt. Cbll-c (i.e. Colline stage/Medio-European sub-stage) occurs especially in the western Apennine, in valleys near the main Apennine ridge. The RPM classifies these areas, in part as cool submediterranean belt, in part as submontane belt;

In summary, major challenges to matching zonal/ etageal potential vegetation and DSPS were found:

- in areas where the transition from one stage to another are not sharply delineated, and different vegetation types are intermixed;

- in alluvial lowland, probably because of the dominance of edaphic factors;

- in strongly anthropized areas, where (semi)natural ecosystems are almost completely absent. Likewise, on anthropized lands, PME shows a drier stage than indicated by relic vegetation because of altered interactions on the climate-vegetation-soil system. 
Defaut (1996) has already noted this fact. Before Defaut, Stewart (in Daget 1977) and Daget (1977) have discussed a similar issue with the Emberger bioclimatic system.

\subsection{DSPS and ecological regionalization.}

Numerous techniques to define ecological land units have been proposed. Bailey (2009) reviews the followings: Gestalt, map-overlay, multivariate clustering, digital-image processing and controlling factors. In the last decades, controlling factors and multivariate clustering methods have been widely used.

Ecological regionalization based on hierarchy of controlling factors were developed in Canada (Wiken \& Ironside 1977), the USA (Bailey 1976), the Netherlands (Klijn \& de Haes 1994). The original concepts and works of Holdridge $(1947,1967)$ and Walter \& Box (1976) can be included in this approach. Summarizing, this approach consists in defining ecological land units by using an environmental factor considered the driving factor at a given level of hierarchy. Generally, at the highest rank of the hierarchy, the driving factor is climate, at the intermediate ranksaregeology and geomorphology, and at the lower ranks are soils, water, vegetation, animals and man. The resulting ecological land units are generally named "ecoregions". The reader is referred to Bailey $(1987,2009)$, Kijn\& de Haes (1994) and Klijn (1997) who extensively discuss concepts and techniques regarding a controlling factors approach. One of the advantages of this method consists in its relative simplicity, because each hierarchical level of the classification is based on a single environmental factor considered the ecological driver at the scale of interest. Concerns arise about the subjectivity in choosing the driving factors and their rank in the hierarchy. According to Lugo et al. (1999) the controlling factor regionalizations "have limited value for assessing ecosystem functioning because they do not consistently address the driving factors of ecosystems and place too much significance on size or space-driven hierarchies". Likely, the stress of many controlling factors regionalizations on size and geographical space could be due to the fact that they are often developed by land managers with a purpose of planning and managing lands. On the other hand,
Bailey (1987, 2009), Klijn (1997) and others have demonstrated the validity of regionalization with many examples.

Multivariate clustering gained popularity in the last years thanks to the improvement of statistical techniques, increase of computerized calculus capacity and availability of environmental data. This strictly statistical approach consists in clustering a set of ecological variables in an environmental space. Clusters can be subsequently projected in the geographical space, also in hierarchized groups. Environmental Domains were developed e.g. in New Zealand (Leathwick et al. 2003), Antarctica (Morgan et al. 2007), Canada (Coops et al. 2009), Switzerland (Lehmann et al. 2010) and Europe (Mücher et al. 2010). Multivariate clustering is a very valuable tool in ecological studies; however, some authors have criticized particular aspects of the method. According to Rubel \& Kottek (2011), results of clustering analysis "are sometimes difficult to interpret". According to Bailey (2009) multivariate clustering creates units (clusters) of similar cells that are not necessarily ecological, because an ecological unit "is a pattern of spatially associated, but unlike component land units" and "ecological units can be comprehended only as wholes that have some process significance". Heterogeneity, spatial or chorological relationships and scale are key concepts in landscape ecology and ecosystem regionalization (e.g. Forman \& Godron 1986; Klijn \& de Haes 1994; Krönert et al. 2001). Ecosystems, at a given scale, are composed by heterogeneous patches linked by ecological processes, and generally, by geographical proximity. The controlling factor links internal heterogeneous patches of the ecological land unit to the scale of interest (Klijn \& de Haes 1994; Bailey 2009). In addition, note also that regionalization based on clustering is not completely objective. For example, the choice of input variables and the number clusters are subjective. Indeed, sometimes numbers of final clusters are intended to compare classifications to older ones (e.g. Canada, see Coops et al. 2009), other times the number of clusters is a political choice (e.g. Antarctica, see Morgan et al. 2007), and yet other times the classification tries to match existing biogeographical regions (e.g. Europe, see Mücher et al. 2010). 
This report suggests that DSPS is not only useful for ecological studies, but also for landscape/ecological regionalization efforts. DSPS could be the highest rank in a hierarchical classification based on controlling factors. To be operational, such hierarchical ecological regionalization should be integrated by other (lower) ranks including appropriate controlling factors, e.g. geomorphology, water, soil, vegetation, and last but not least, anthropogenic influence. Although many feedback loops exist, generally human activities modify ecosystems at lower hierarchical ranks (Holdridge 1967; Forman \& Godron 1986). In addition, the use of DSPS should take into account the weaknesses discussed above. Whereas the Phytoclimatic Map of Europe (Botti 2018) investigated the spatial distribution of DSPS' phytoclimatic units at the continental scale, the present study is focused at a more detailed scale. Both studies and both scales of interest seem to suggest the validity of the DSPS. DSPS on the one hand has the disadvantage of DSPS being limited to Palearctic (and tentatively, part of Afrotropic lowland), but on the other hand permits more specificity and detail, with respect to other classifications. In addition, it provides some advantages with respect e.g. to Köppen-Trewartha (Trewartha \& Horn 1980) (used by Bailey 1976), Walter \& Box (1976) and Troll \& Paffen (1964) classifications. First, DSPS does not disregard highlands, instead its stages are bioclimatic units including all stations characterized by similar temperature and aridity/humidity. Indeed, in extratropical areas characterized by similar biogeographical history, it is possible to consider altitudinal belts as "as more or less modified outliers of the corresponding latitudinal zones" (Schroeder 1983, 1998). Second, DSPS is more quantitative and requires less expertise than Walter's classification. Third, different from Köppen's and Troll-Paffen's classifications (see e.g. Bailey 1948, 1965), DSPS uses the same variables to differentiate its units. In other words, DSPS ordinates vegetation (the more visible expression of ecosystems) in an ecological gradient space (Whittaker 1970). Perhaps it would not be unreasonable to say that, like the Holdridge Life Zone Model (Holdridge 1947, 1967), it "formalizes the identification of ecological space, i.e. it identifies the climatic conditions that result in particular ecosystem functioning over particular geographical space" (Lugo et al. 1999).
Two of the advantages claimed by Defaut (1996) about DSPS, are that it is simpler than other bioclimatic classifications, and likely more important, its phytoclimatic stages and thresholds are drawn directly from vegetation patterns. From one point of view, DSPS is the opposite when compared to the multivariate clustering approach. Defaut has plotted vegetation types in an environmental space defined by T, tc, tc-tf and QN2, and then has traced borders (i.e. boundaries of phytoclimatic stages) among clusters formed by vegetation in that environmental space. Generally, in multivariate clustering methods, environmental variables are clustered to form regions and subsequently, is possible to assign vegetation types or biomes to those regions. It is true that vegetation lies in the lower ranks of hierarchical controlling factor regionalizations (e.g. Klijn \& de Haes 1994), but at the same time, vegetation is the most important and visible aspect of ecosystem, and this opinion is supported by the strict relationship between climate and vegetation classifications (de Laubenfels 1975). The difficulties arise on how and what types of vegetation should be considered. DSPS is based on zonal/etageal natural potential vegetation. Some authors (e.g. Chiarucci et al. 2010) have criticized the Natural Potential Vegetation (NPV) concept in being too deterministic and static, whereas real vegetation is dynamic and stochastic. In any case, the NPV concept still seems useful, for instance as a baseline for planning and comparison between different scenarios (see e.g Somodi et al. 2012).

DSPS suffers some weaknesses common to other bioclimatic classifications. First, the sharpness of boundaries between units. Sharpness of boundary is useful in land classifications purposed for planning and management, but in the real world, ecological units do not have only sharp borders, as in areas with relief, but also smooth borders, or intermixed in large ecotones. To solve this problem, some authors consider transitional areas between major units (e.g. Holdridge 1947, 1967; Walter \& Box 1976). Other authors introduced different types of borders (Hargrove \& Hoffman 1999). Another very important issue is the subjectivity of the method. Obviously, subjectivity plays a role in all approaches. 
As shown by the example of E-R phytoclimatic map (Fig. 10), it seems relatively easy to translate data from other systems to Defaut's. The map provided of E-R's phytoclimatic units, based on 1961-90 climatological data and on vegetation recorded in the RPM map (Ubaldi et al. 1996) could be the benchmark for future studies about vegetation and climate change, and their relationship. Furthermore, this map could represent the highest level in a future ecological regionalization of the area.

In conclusion, this study indicates that the DSPS is predictive, and Defaut's results are confirmed at a detailed scale and in two regions not previously investigated. DSPS could be a valuable tool in ecological regionalization and landscape analysis.

\section{Acknowledgments}

The author thanks sincerely: Dr. Bernard Defaut, for a positive exchange of opinions; Mr. Chris Matera, for the English proofreading; and two anonymous reviewers for helpful comments and suggestions.

\section{References}

Agenzia regionale prevenzione, ambiente ed energia Regione Emilia-Romagna Arpae. Tabelle climatologiche, Idro-Meteo-Clima, (https://www. arpae.it/sim/?osservazioni_e_dati/climatologia) (Date: 22.03.2016).

Agenzia regionale per la protezione dell'ambiente ligure Arpal. Atlante climatico della Liguria, (https://www.arpal.gov.it/homepage/meteo/ analisi-climatologiche/atlante-climatico-dellaliguria.html) (Date: 07.10.2016).

Baden-Württemberg. Geografie. https://www. baden-wuerttemberg.de/de/unser-land/landund-leute/geografie/ (Date : 25.05.2016).

Bailey, H. P. 1948. Proposal for a Modification of Koeppen's Definitions of the Dry Climates.
Yearbook of the Association of Pacific Coast Geographers 10(1), 33-38. DOI: 10.1353/ pcg.1948.0003

Bailey, H. P. 1965. Weltkarten zur Klimakunde. World Maps of Climatology.Weltkarten zur Klimakunde. World Maps of Climatology by H. E. Landsberg; H. Lippmann; Kh. Paffen; C. Troll; E. Rodenwaldt \& H. J. Jusatz. Review by: Harry P. Bailey. Geographical Review 55(3), 455-458. DOI: 10.2307/213150

Bailey, R. G. 1976. Ecoregions of the United States. USDA Forest Service, Intermountain Region, Ogden, UT. 1:7,500,000; colored.

Bailey, R. G. 1987. Suggested hierarchy of criteria for multi-scale ecosystem mapping. Landscape and Urban Planning 14, 313-319. DOI: 10.1016/01692046(87)90042-9

Bailey, R. G. 2009. Ecosystem geography: from ecoregions to sites (second ed.). Springer, New York Dordrecht Heidelberg London. DOI: 10.1007/978-0-387-89516-1

Biondi, E.; Allegrezza, M.; Casavecchia, S.; Pesaresi, S. \& Vagge I. 2006. Lineamenti vegetazionali e paesaggio vegetale dell'Appennino centrale e settentrionale. Biogeografia dell'Appennino Centrale e Settentrionale: trent'anni dopo 27, 35129. Società Italiana di Biogeografia, I'Aquila. DOI: $10.21426 / \mathrm{b} 6110001$

Bohn, U.; Neuhäusl, R.; Gollub, G.; Hettwer, C.; Neuhäuslová, Z.; Raus, T.; Schlüter, H. \& Weber H. 2000/2003. Karte der natürlichen Vegetation Europas / Map of the Natural Vegetation of Europe. Maßstab / Scale 1 : 2,500,000. Landwirtschaftsverlag, Münster.

Botti, D. 2018. A phytoclimatic map of Europe. Cybergeo : European Journal of Geography (867). DOI: $10.4000 /$ cybergeo.29495

Box, E. O. 1981. Predicting physiognomic vegetation types with climate variables. Vegetatio 45(2), 127-139. DOI: 10.1007/bf00119222 
Box, E. O. \& Fujiwara, K. 2005. Vegetation types and their broad-scale distribution. In E. v. Maarel (ed.): Vegetation ecology. Blackwell Science Ltd., Malden, Oxford, Carlton.

Box, E. O. \& K. Fujiwara 2015. Warm-temperate deciduous forests: concept and global overview. In: Box, E. O. \& K. Fujiwara (eds.): WarmTemperate Deciduous Forests around the Northern Hemisphere. Springer International Publishing. DOI: 10.1007/978-3-319-01261-2_2

Chiarucci, A.;Araújo, M. B.; Decocq, G.; Beierkuhnlein, C. \& Fernández-Palacios, J. M. 2010. The concept of potential natural vegetation: an epitaph? Journal of Vegetation Science 21(6), 1172-1178. DOI: 10.1111/j.1654-1103.2010.01218.x

Conrad, O.; Bechtel, B.; Bock, M.; Dietrich, H.; Fischer, E.; Gerlitz, L.; Wehberg, J.; Wichmann, V. \& Boehner, J. 2015. System for Automated Geoscientific Analyses (SAGA) v. 2.1.4. Geoscientific Model Development, 8, 1991-2007. DOI:10.5194/gmd-8-1991-2015.

Coops, N. C.; Wulder, M. A. \& Iwanicka, D. 2009. An environmental domain classification of Canada using earth observation data for biodiversity assessment. Ecological Informatics 4(1), 8-22. DOI: 10.1016/j.ecoinf.2008.09.005

De Laubenfels, D. J. 1975. Mapping the world's vegetation: regionalization of formations and flora, Syracuse, Syracuse University Press.

Defaut, B. 1991. Vers une modélisation de l'evolution climatique au Quaternaire. BRGM, Orléans.

Defaut, B. 1992. Données complémentaires sur les relations entre climat actuel et étages de végétation dans le domaine paléarctique. BRGM, Orléans.

Defaut,B.1996. Unsystèmed'étages phytoclimatiques pour le domaine paléarctique. Corrélations entre végétation et paramètres climatiques. Matériaux Entomocénotiques 1, 5-46.
Defaut, B. 2001. Carte de la végétation de la France. Matériaux Entomocénotiques 6, 113-121.

Defaut, B. 2015. Nouvelles considérations sur les phytoclimats du Maroc. Application au Maroc oriental. Matériaux orthoptériques et entomocénotiques 20, 97-106.

Emberger, L. 1939. Aperçu général sur la végétation du Maroc. Veröffentlichungen des Geobotanischen Institutes Rübel in Zürich 14, 40 - 157.

Emberger, L.1955. Uneclassification biogéographique des climats. Recueil des Travaux des Laboratoires de Botanique, Géologie et Zoologie de la Faculté des Sciences de L'Université de Montpellier. Série Botanique 7, 3-43.

Emberger, L. 1964. La position phytogéographique du Maroc dans l'ensemble méditerranéen. AlAwamia 12, 1-15.

Federal Office of Meteorology and Climatology MeteoSwiss, 2016. „Normal values per measured parameter", Swiss climate in detail (https:// www.meteoswiss.admin.ch/home/climate/ swissclimate-in-detail/climate-normals/normalvalues-per-measured-parameter.html) (Date: 22.03.2016).

Ferrari, C. 1997. Le fasce di vegetazione dell'EmiliaRomagna. In: M. Tomaselli (ed.): Guida alla vegetazione dell'Emilia-Romagna. Università di Parma, Parma.

Forman, R. T. \& Godron M. 1986. Landscape Ecology. John Wiley \& Sons, New York.

Forstliche Versuchs- und Forschungsanstalt, BadenWürttemberg 1997. Standortskundliche regionale Gliederung. - Forstliche Standortskartierung Baden-Württemberg. Karten 1:1,000,000 und $1: 650,000$. Abteilung Botanik und Standortskunde, Freiburg i. Br. 
Gamper, U. Filesi, L.; Buffa, G. \& Sburlino G. 2008. Diversità fitocenotica delle dune costiere nord-adriatiche 1 - Le comunità fanerofitiche. Fitosociologia 45, 3-21.

Gaussen H. 1957. Les ensembles écologiques de la péninsule hispanique. Publicaciones del Instituto de Biología Aplicada, Barcelona 26, 9-17.

Iwahashi,J.\&Pike,R.J.2007. Automated classifications of topography from DEMs by an unsupervised nested-means algorithm and a three-part geometric signature. Geomorphology 86(3-4), 409-440. DOI: 10.1016/j.geomorph.2006.09.012

Hargrove, W. W. \& Hoffman, F. M. 1999. Using multivariate clustering to characterize ecoregion borders. Computing in science \& engineering 1(4), 18-25. DOI: 10.1109/5992.774837

Holdridge, L. R. 1947. Determination of world plant formations from simple climatic data. Science 105 (2727), 367-368. DOI: science.105.2727.367

Holdridge, L.R. 1967. Life zone ecology (rev. ed.). Tropical Science Center, San Jose, Costa Rica.

Klijn, F. 1997. A hierarchical approach to ecosystems and its implications for ecological land classification: with examples of ecoregions, ecodistricts and ecoseries of the Netherlands. $\mathrm{CML}$, Leiden.

Klijn, F., \& H. de Haes 1994. A hierarchical approach to ecosystems and its implications for ecological land classification. Landscape Ecology 9 (2), 89104. DOI: $10.1007 /$ bf00124376

Krönert, R.; Steinhardt, U. \& Volk, M. (eds.) 2001. Landscape balance and landscape assessment. Springer-Verlag, Berlin - Heidelberg. DOI: 10.1007/978-3-662-04532-9

Küchler, A. W. 1967. Vegetation mapping. Ronald Press Company, New York.
Landesanstalt für Umwelt Baden-Württemberg LUBW 1992. Potentielle natürliche Vegetation und Naturräumliche Einheiten. http://www4. lubw.baden-wuerttemberg.de/servlet/is/36565/ (Date: 23.11.2015).

Leathwick, J. R.; Overton, J. M.\& McLeod, M. 2003. An environmental domain classification of New Zealand and its use as a tool for biodiversity management. Conservation biology 17(6), 16121623. DOI: 10.1111/j.1523-1739.2003.00469.x

Lehmann, A.; Allenbach, K.; Maggini, R.; Richard, J. P.; Jacquet, J. M. \& Dao, H. 2010. Swiss environmental domains: a new spatial framework for reporting on the environment, Environment. Federal Office for the Environment FOEN, Environmental studies no. 1024 , Bern.

Lugo, A. E.; Brown, S. L.; Dodson, R.; Smith, T. S. \&Shugart, H. H. 1999. The Holdridge life zones of the conterminous United States in relation to ecosystem mapping. Journal of biogeography 26(5), 1025-1038. DOI: 10.1046/j.13652699.1999.00329.x

Morat, P. 1969. Note sur I'application à Madagascar du quotient pluviothermique d'Emberger. Cahiers ORSTOM. Série Biologie 10, 117-132.

Morgan, F.; Barker, G.; Briggs, C.; Price, R.; Keys, H. \& Zealand, A. N. 2007. Environmental domains of Antarctica (version 2.0 final report). Manaaki Whenua Landcare Research New Zealand Ltd, 89.

Mücher, C. A.; Klijn, J. A.; Wascher, D. M. \& Schaminée, J. H. 2010. A new European Landscape Classification (LANMAP): A transparent, flexible and user-oriented methodology to distinguish landscapes. Ecological indicators 10(1), 87-103. DOI: 10.1016/j.ecolind.2009.03.018

Mühr, B. 2010. Das Klima in Baden-WürttembergKlimadiagramme weltweit. http://www. klimadiagramme.de/Bawue/bawue.html (Date: 03.02.2016). 
Müller, T.; Oberdorfer, E. \& Philippi G. 1974. Die potentielle natürliche Vegetation von BadenWürttemberg. Ludwigsburg: Landesstelle für Naturschutz und Landschaftspflege BadenWürttemberg.

Oberdorfer, E. 1968. Studien in den Wäldern des Carpinion-Verbandes im Apennin an der Südwestgrenze des Vorkommens von Carpinus betulus. Feddes Repertorium 77(1), 65-74. DOI: 10.1002/fedr.19680770108

Ozenda, P. 2002. Perspectives pour une géobiologie des montagnes. Presses polytechniques et universitaires romandes, Lausanne.

Perera, N. P. 1968. Some Problems of ClimateVegetation Correlations with Special Reference to Ceylon. Vidyodaya Journal of Arts, Science, and Letters 1, 173-184.

Perosino G. C. \& Zaccara P., 2006. Elementi climatici del Piemonte. C.R.E.S.T. - Centro Ricerche in Ecologia e Scienze del Territorio, Torino (http:// www.crestsnc.it/) (Date: 07.10. 2016).

Piccoli, F. 1997. La vegetazione della bassa Pianura Padana. In: M. Tomaselli (ed.): Guida alla vegetazione dell'Emilia-Romagna. Università di Parma, Parma.

Poli E. 1965. La vegetazione altomontana dell‘Etna. Flora et Vegetatio Italica, mem. 5. Sondrio.

Puppi Branzi, G. 1997. La vegetazione collinare e montana dell'Emilia-Romagna. In: M. Tomaselli (ed.): Guida alla vegetazione dell‘Emilia-Romagna. Università di Parma, Parma.

Reidl, K.; Suck, R.; Bushart, M.; Herter, W.; Koltzenburg, M.; Michiels, H. G.; Wolf, Th.; Aminde, E. \& Bortt W. 2013. Potentielle Natürliche Vegetation von Baden-Württemberg. Karlsruhe: LUBW Landesanstalt für Umwelt, Messungen und Naturschutz Baden-Württemberg, Naturschutz Spectrum Themen.
Rivas-Martinez S. 1987. Memoria del Mapa de series de Vegetación de España 1:400,000. ICONA, Madrid.

Rubel, F. \& Kottek, M. 2011. Comments on:"The thermal zones of the Earth" by Wladimir Köppen (1884). Meteorologische Zeitschrift 20(3), 361365. DOI: 10.1127/0941-2948/2011/0285

Schroeder, F. G. 1983. Die thermischen Vegetationszonen der Erde: ein Beitrag zur Präzisierung der geobotanischen Terminologie mit einer Vegetationskarte. Tuexenia (3), 31-46.

Schroeder, F. G. 1998. Lehrbuch der Pflanzengeographie. Quelle \& Meyer, Wiesbaden.

Scripter M. 1970. Nested-Means Map Classes for Statistical Maps. Annals of the Association of American Geographers 60(2), 385-393. DOI: 10.1111/j.1467-8306.1970.tb00727.x

Somodi, I.; Molnár, Z.\& Ewald, J. 2012. Towards a more transparent use of the potential natural vegetation concept-an answer to Chiarucci et al. Journal of Vegetation Science 23(3), 590-595. DOI: 10.1111/j.1654-1103.2011.01378.x

Svenning, J. C. \& Skov, F. 2004. Limited filling of the potential range in European tree species. Ecology Letters 7(7), 565-573. DOI: 10.1111/j.14610248.2004.00614.x

Trewartha, G. T. \& Horn, L. H. 1980. An Introduction to Climate-McGraw-Hill, New York.

Troll, C. \& Paffen K. H. 1964. Karte der JahreszeitenKlimate der Erde. Erdkunde 18, 1-28. DOI: 10.3112/erdkunde.1964.01.02

Touring Club Italiano - TCl. 2005. Emilia-Romagna. Touring Club Italiano, Roma.

Tomaselli, M. 1997. La vegetazione soprasilvatica dell'Appennino Tosco-Emiliano. In: M. Tomaselli (ed.): Guida alla vegetazione dell‘Emilia-Romagna. Università di Parma, Parma. 
Ubaldi, D. 1980. La fascia collinare e submontana. In: C. Ferrari (ed.): Flora e vegetazione dell'EmiliaRomagna. Regione Emilia-Romagna.

Ubaldi, D., Puppi, G., \& A. L. Zanotti 1996. Carta fitoclimatica dell'Emilia-Romagna 1:500,000. Regione Emilia Romagna Assessorato Territorio Programmazione e Ambiente, Studi e Documentazioni 47, 1-79.

Vianelli, M. 1998. Il clima. In: Antonioli, N. \& Cazzola M. (eds.): Parco Regionale Alto Appennino Modenese. Collana Aree Protette della Regione Emilia-Romagna 8. Giunti Gruppo Editoriale, Firenze.

Walter, H. 1985. Vegetation of the earth and ecological systems of the geo-biosphere. SpringerVerlag, Berlin. DOI: 10.1007/978-3-642-96859-4

Walter, H. \& Box, E. 1976. Global classification of natural terrestrial ecosystems. Vegetatio 32(2), 75-81. DOI: 10.1007/bf02111901

Whittaker, R. H. 1970. Communities and ecosystems. Macmillan, London.

Wiken, E. B. \& Ironside, G. 1977. The development of ecological (biophysical) land classification in Canada. Landscape Planning 4: 273-275. DOI: 10.1016/0304-3924(77)90029-6

Wikipedia, „Dati climatologici 1961-1990“, Stazioni meteorologiche d'Italia (https://it.wikipedia.org/ wiki/Categoria\%3AStazioni_meteorologiche_d'It alia?oldid=78849522) (Date: 24.10 .2016 ) 